\title{
Microphytoplankton variations during coral spawning at Los Roques, southern-Caribbean
}

Francoise Cavada-Blanco, Ainhoa L Zubillaga, Carolina Bastidas

Phytoplankton drives primary productivity in marine pelagic systems. This is also true for the oligotrophic waters in coral reefs, where natural and anthropogenic sources of nutrients can alter pelagic trophic webs. In this study, microphytoplankton assemblages were characterized for the first time in relation to expected coral spawning dates in the Caribbean. A hierarchical experimental design was used to examine these assemblages in Los Roques archipelago, Venezuela, at various temporal and spatial scales for spawning events in both 2007 and 2008. At four reefs, superficial water samples were taken daily for 9 days after the full moon of August, including days before, during and after the expected days of coral spawning. Microphytoplankton assemblages comprised 100 microalgae taxa at up to 50 cells per $\mathrm{mL}$ (mean $\pm 8 \mathrm{SD}$ ) and showed temporal and spatial variations related to the coral spawning only in 2007. However, chlorophyll a concentrations increased during and after the spawning events in both years, and this was better matched with analyses of higher taxonomical groups (diatoms, cyanophytes and dinoflagellates), that also varied in relation to spawning times in 2007 and 2008, but asynchronously among reefs. Heterotrophic and mixotrophic dinoflagellates increased in abundance, correlating with a decrease of the diatom Cerataulina pelagica and an increase of the diatom Rhizosolenia imbricata. These variations occurred during and after the coral spawning event for some reefs in 2007. For the first time, a fresh-water cyanobacteria species of Anabaena was ephemerally found (only 3 days) in the archipelago, at reefs closest to human settlements. Variability among reefs in relation to spawning times indicated that reef-specific processes such as water residence time, re-mineralization rates, and benthicpelagic coupling can be relevant to the observed patterns. These results suggest an important role of microheterotrophic grazers in re-mineralization of organic matter in coral reef waters and highlight the importance of assessing compositional changes of larger size fractions of the phytoplankton when evaluating primary productivity and nutrient fluxes. 
1 Microphytoplankton variations during coral spawning at Los Roques, southern-

3 Francoise Cavada-Blanco ${ }^{1 *}$, Ainhoa L. Zubillaga ${ }^{2}$, Carolina Bastidas ${ }^{2,3}$

4 1'Laboratorio Conservación Marino-Costera, Departamento de Estudios Ambientales, 5 Universidad Simón Bolívar, Caracas, Venezuela

6 2Laboratorio de Ecotoxicología y Comunidades Marinas, Departamento de Biología de

7 Organismos, Universidad Simón Bolívar, Caracas, Venezuela

$8 \quad{ }^{3}$ Current address: MIT Sea Grant College Program, Cambridge MA, USA

\section{Correspondence:}

10 Msc. Francoise Cavada-Blanco, Laboratorio de Conservación Marino-Costera, 11 Departamento de Estudios Ambientales, Universidad Simón Bolívar, PA4-013, Carretera El 12 Placer-Hoyo de La Puerta, Baruta, Edo. Miranda 9800, Venezuela.

13 fcavada@usb.ve

\section{Abstract}

15 Phytoplankton drives primary productivity in marine pelagic systems. This is also true for 16 the oligotrophic waters in coral reefs, where natural and anthropogenic sources of nutrients can alter pelagic trophic webs. In this study, microphytoplankton assemblages were characterized for the first time in relation to expected coral spawning dates in the Caribbean. A hierarchical experimental design was used to examine these assemblages in Los Roques archipelago, Venezuela, at various temporal and spatial scales for spawning 21 events in both 2007 and 2008. At four reefs, superficial water samples were taken daily for 229 days after the full moon of August, including days before, during and after the expected 23 days of coral spawning. Microphytoplankton assemblages comprised 100 microalgae taxa 24 at up to 50 cells per $\mathrm{mL}$ (mean $\pm 8 \mathrm{SD}$ ) and showed temporal and spatial variations related 25 to the coral spawning only in 2007. However, chlorophyll a concentrations increased 26 during and after the spawning events in both years, and this was better matched with 27 analyses of higher taxonomical groups (diatoms, cyanophytes and dinoflagellates), that also 
28 varied in relation to spawning times in 2007 and 2008, but asynchronously among reefs.

29 Heterotrophic and mixotrophic dinoflagellates increased in abundance, correlating with a

30 decrease of the diatom Cerataulina pelagica and an increase of the diatom Rhizosolenia

31 imbricata. These variations occurred during and after the coral spawning event for some

32 reefs in 2007. For the first time, a fresh-water cyanobacteria species of Anabaena was

33 ephemerally found (only 3 days) in the archipelago, at reefs closest to human settlements.

34 Variability among reefs in relation to spawning times indicated that reef-specific processes

35 such as water residence time, re-mineralization rates, and benthic-pelagic coupling can be

36 relevant to the observed patterns. These results suggest an important role of

37 microheterotrophic grazers in re-mineralization of organic matter in coral reef waters and

38 highlight the importance of assessing compositional changes of larger size fractions of the

39 phytoplankton when evaluating primary productivity and nutrient fluxes.

40 1. Introduction

41 Phytoplankton drives the energy flow in most marine ecosystems as they are the main 42 primary producers in environments where sufficient light allows for photosynthetic 43 fixation of carbon (C) (Reynolds, 2006). In coral reefs, this productivity appears to be 44 limited by nitrogen $(\mathrm{N})$, as reef waters usually have minimal macronutrient concentrations 45 (Charpy-Roubaud 1990; Furnas et al., 1990; Dizon \& Yap, 1999; Koop et al., 2001; Heil et 46 al., 2004). Nutrients and organic compounds enter the typically oligotrophic waters of coral 47 reefs constantly through different pathways, from either natural or anthropogenic sources 48 (Wild et al., 2004; Wolanski et al., 2004; Mumby et al,. 2007; Hoegh-Guldberg et al., 2007). 49 For instance, various recirculation processes in reefs drive fluxes of submarine 50 groundwater that might transfer in-land nitrogen into the reefs (Santos et al., 2010). Other 51 52 spawning events, also represent influxes of labile organic compounds, from which the 53 composition and amount of organic matter released into the water column varies greatly in 54 space and time (Coffroth 1990, 1991; Wild et al., 2004). Anthropogenic sources of nutrients 55 are often derived from land-based pollution, such as coastal development and agriculture 56 on watersheds, among other activities (Burke et al., 2011). 
57 Regardless of the source, a surplus of organic or inorganic nutrients in coral reefs can alter 58 the ecosystem biogeochemistry and both the pelagic and benthic food webs (Koop et al., 59 2001; Eyre et al., 2008). For example, dissolved inorganic nutrients seem to be rapidly 60 incorporated by the phytoplankton (Fabricius et al., 2013), but chronic inputs might lead to 61 higher oxygen demand, through phyto-, bacterio- and zooplankton overgrowth and 62 decomposition (Lapointe \& Clark, 1992). Nutrient addition is a well-documented driver of 63 taxonomical and biomass changes in marine phytoplankton assemblages (Piehler et al., 64 2004; Furnas et al., 2005; Howardth \& Marino, 2006; Pirela-Ochoa et al., 2008; Strom, 65 2008; Mutshinda et al., 2013). Seasonal changes in phytoplankton composition in 66 oligotrophic ocean waters, upwelling sites and coastal waters in response to both organic 67 and inorganic nutrient inputs have been reported round the world (Casas et al., 1997; Bode 68 et al., 2001; Oguz et al., 2001; Vuorio et al., 2005; Wu et al., 2005; Harris, 2012).

69 In coral reefs, phytoplankton is dominated by small-size fractions $(<2 \mu \mathrm{m})$ such as the 70 cyanobacteria Synechococcus and Prochlorococcus (Furnas \& Mitchell 1989; Furnas et al., 71 2005). This small-size fraction has been the focus of studies into the response of pelagic 72 primary producers to coral spawning events, as this response has been mainly evaluated 73 using biomass and pigment concentrations (Eyre et al., 2008; Glud et al., 2008; Wild et al., 74 2008; Apprill \& Rappé, 2011; Patten et al., 2011). However, species of larger sizes (i.e. 75 nano- and microphytoplankton: 2 to $200 \mu \mathrm{m}$ ), especially diatoms, also increase their 76 primary production with nutrient inputs in coral reefs (Furnas, 1991; Crosbie \& Furnas, 77 2001). As a result of nutrient input and cell division, larger sizes achieve greater 78 abundances in shallow waters than in oceanic waters (Duyl et al., 2002); suggesting that 79 these microalgae might also play an important role in nutrient uptake and pelagic trophic 80 webs in coral reefs.

81 For example, a nutrient input after a typhoon that occurred in a reef in French Polynesia, 82 was followed by an increase in phytoplankton biomass and primary productivity, and by a 83 change in taxonomic composition of the microphytoplankton (Delesalle et al., 1993). Also, 84 Glud et al. (2008) reported a dinoflagellate bloom in a reef flat after a coral spawning in the 85 Great Barrier Reef; and Horne (2011) detected an increased abundance of the 86 dinoflagellate Ceratium spp. 2 days after a spawning event in the Gulf of Mexico. As coral 
87 spawning events constitute an input of nutrients in coral reefs (Wild et al., 2004b; Eyre et 88 al., 2008; Glud et al., 2008; Wild et al., 2008; Patten et al., 2011), and growth of various 89 microphytoplankton groups is nitrogen limited (Hauss et al., 2012), it would be expected 90 that this input of nutrients affects the abundance and composition of larger size fraction.

91 Coral spawning events have been used as large natural experiments to understand the 92 effects of an episodic organic matter input on phytoplankton primary productivity and 93 biomass in coral reef systems (Wild et al., 2001, 2004b, 2008; Eyre et al., 2008; Glud et al., 94 2008; Patten et al., 2011; Apprill \& Rappé 2011). After coral spawning, Wild et al. (2004) 95 reported an increase in sediment oxygen demand and Glud et al. (2008) found an increased 96 pelagic and benthic primary production. Similarly, Eyre et al. (2008) showed a post97 spawning peak in phytoplankton biomass coinciding with the removal of dissolved 98 inorganic nutrients and changes in nitrogen cycling on the top layer of the sediment. 99 Nutrient additions through mass coral spawning events are thus expected to drive changes 100 in the nitrogen and phosphorous concentrations, and consequently have effects on 101 autotrophic and heterotrophic communities on reefs.

102 Reproductive timing of most common coral species in the Caribbean is well known 103 (Szmant, 1986; Bak \& Engle, 1979; Fadlallah, 1983; deGraaf et al., 1999; Budd, 1990; 104 Bassim et al., 2002; Carlon, 2002, Brooke \& Young, 2003; Beaver et al., 2004; Bastidas et al., 105 2005; Severance \& Karl, 2006); however, the effects of this event on the reef's pelagic 106 trophic web have not yet been documented in the region. To contribute to this knowledge, 107 herein we describe changes on the composition and abundance of the microphytoplankton 108 assemblages at various spatial and temporal scales at Los Roques, Venezuela during 2007 109 and 2008 coral spawning events. As Los Roques is an oceanic archipelago with a marginal 110 and local source of anthropogenic nutrients, expected coral spawning dates are a good 111 opportunity to assess the effects of a natural source of organic nutrients on the 112 composition and abundance of microphytoplankton separately from those of human 113 sources.

\section{2. Materials and Methods}

115 2.1. Study Site 
116 Los Roques National Park is the most important reef complex in Venezuela, as well as in the 117 Southern Caribbean (Casanova et al., 2007). Los Roques is located $160 \mathrm{~km}$ north of the 118 coast (66.55-66.95 W 11.65-11.98 N; Fig. 1), and the archipelago encompasses more than 11950 coralline cays that are protected from wave exposure by two barrier reefs: the eastern 120 barrier and the southern barrier, which are $20 \mathrm{~km}$ and $30 \mathrm{~km}$ long, respectively (Méndez121 Baamonde, 1978). Los Roques was the first marine area in Venezuela to be protected under 122 the category of National Park and is part of the southern corridor, one of the most 123 important areas in the Caribbean region in terms of biodiversity and extension (Rodríguez124 Ramírez, 2008). The human population at Los Roques (approximately 2,000) is 125 concentrated in the Northeast, specifically on Gran Roque. In the Southwest there is no 126 permanent settlement and it is relatively less affected by recreational and fishing activities; 127 thus, anthropogenic nutrient sources in the archipelago are marginal when compared with 128 coastal reefs. Studies on biological and physicochemical oceanography are scarce and 129 limited at Los Roques, however there have been studies describing temporal variability in 130 zooplankton and phytoplankton composition and abundance at one or two reefs (González, 131 1989; Spiniello, 1996, Madera \& Furderer, 1997), and a seasonal variation has been found 132 in relation to the drought (November-July) and rain (May-October) regimes.

\section{2.2. Sample Collection}

134 To assess variations in microphytoplankton assemblages in relation to coral spawning at 135 Los Roques, a hierarchical design was employed considering the following factors: 1) 136 Locality (fixed, crossed with two levels: Northeast (NE) and Southwest (SW); 2) Reef 137 (random, nested in locality with two levels: Gran Roque (GR) and Madrizquí (MD) on the 138 NE and Dos Mosquises (DMS) and Cayo de Agua (CYA) on the SW); and 3) Period (fixed, 139 crossed with three levels: before, during and after the expected spawning dates). The 140 samples were taken from a motor boat by gently submerging a sterile 1,000 mL plastic 141 bottle in the water down to $\sim 0.5$ to $1 \mathrm{~m}$ depth until filled. Samples were taken by two 142 different teams at approximately the same hour (9:00-10:00 a.m.) in the NE and SW reefs, 143 while samples were collected less than one hour apart between reefs of the same locality. 144 The samples were then fixed with 10\% formalin, stabilized with sodium tetraborate and 145 closed with a sealed cap. Samples were transported to the laboratory and stored in a cold 146 dark place until analysis. Four replicate samples were taken daily for 9 consecutive days 
147 after the full moon of August 2007 and 2008 on the basis of the expected dates of 148 spawning. Expected dates for the first coral species that start spawning in these multi149 specific events (i.e., 2 to 4 days after the full moon of August and September, Szmant, 1986) 150 marked the end of the "Before" and the start of the "During" sampling period. These dates 151 are specified for each period and year in Table 1 and were chosen based on extensive 152 observations of coral spawning dates in the Caribbean (e.g. Van Veghel, 1994, Szmant et al., 153 1997; Sánchez et al., 1999; Mendes \& Woodly, 2002) and in our study site (Bastidas et al., 154 2005).

155 The presence of Acropora palmata larvae in the water during the sampling period of this 156 study was further corroborated through specific antibody signals (Zubillaga, 2010). Briefly, 157 the procedure consisted of three steps: (1) inoculation of an Acropora palmata larvae into 158 rabbits; these larvae were harvested in the laboratory from bundles collected from $A$. 159 palmata colonies in the field during a spawning event in 2006; (2) extraction of antibodies 160 from rabbit's blood samples and (3) immunological assays based on ELISA (Enzyme Linked 161 Inmunoabsorbent Assay) to test for specificity and accuracy of the antibodies (Zubillaga 162 2010). The presence of larvae in water samples was detected using a spectrophotometer 163 that measured the colorimetric product of the enzymatic reaction between the antibodies 164 and the coral larvae (Zubillaga 2010). This method was preferred over direct counts due to 165 the superior overall accuracy it has for identifying coral larval species (Carlon \& Olson, 166 1993; Coffroth \& Mulawka, 1995; Garland et al., 2002).

167 TABLE 1. Sampling dates for the Before, During and After periods of coral spawning at Los 168 Roques, according to the expected dates for the first coral species (Acropora palmata and $A$. 169 cervicornis) that start spawning in these multi-specific events 2007

2008

\begin{tabular}{lc|lc}
\hline Period & Date & Period & Date \\
Before & August $28^{\text {th }}-30^{\text {th }}$ & Before & August $16^{\text {th }}-18^{\text {th }}$ \\
During & August $31^{\text {st }-S e p t e m b e r} 2^{\text {nd }}$ & During & August $19^{\text {th }}-21^{\text {st }}$ \\
After & September $3^{\text {rd }}-5^{\text {th }}$ & After & August $22^{\text {nd }}-24^{\text {th }}$
\end{tabular}

170

\section{$171 \quad$ 2.3. Environmental variables}

172 Surface Sea Water Temperature (SST) and chlorophyll a (Chla) concentration $\left(\mathrm{mg} / \mathrm{m}^{3}\right.$ ) 173 were obtained for the sampling dates by satellite image analysis (MODIS SCAR; Klein \& 
174 Castillo, 2010). For this, centroids of the image cells (1 Km x $1 \mathrm{Km}$ spatial resolution) that

175 contained the sampling sites were used to download historical data. No neighbour pixels

176 were used to obtain values of both environmental variables. Due to the proximity between

177 MD and GR, these sampling sites in the northeast fell within the same pixel and thus, SST

178 and Chla had the same values for these reefs.

179 2.4. Sample Processing and Data Analysis

180 Microalgae from the water column were identified to the lowest possible taxonomic level 181 using a Leika D MIL inverted contrast microscope. Samples were analyzed after $48 \mathrm{~h}$ of 182 sedimentation in a $100 \mathrm{~mL}$ settling chamber. The settlement periods were used according 183 with the Utermöhl method for oceanic/oligotrophic samples referred to in Hasle (1978).

184 Phase contrast was used on the same sample to enhance cell detection. Magnification 185 power used for microalgae detection (all fields were viewed) was 200x; however, 400x and 186 1000x magnifications were used for identification. The abundance of microalgae species 187 was calculated using the same protocol, based on the volume of the sample taken. 188 Identification to the lowest possible taxonomic level was performed using Peragallo \& 189 Peragallo (1897-1908), Cupp (1943), Saunders y Glenn (1969), Ferguson (1968), Marshall 190 (1986), La Barbera (1984, 1993), Sournia $(1973,1986)$, Sánchez-Suárez (1992, a,b), Tomas 191 (1997), Berárd-Therriault et al. (1999), Díaz-Ramos (2000) and Krayesky et al. (2009).

192 Microalgae species were grouped into diatoms, dinoflagellates, chlorophytes, cyanophytes 193 and coccolithophores and, based on previous work (Jeong, 1994; Jeong \& Latz, 1994; Jeong 194 et al.. 2004, 2005a, 2005b, 2005c, 2007, 2008, 2010, Du Yoo et al., 2009; Seong et al., 2010), 195 dinoflagellate species were further classified according to trophic functional groups into 196 obligate autotrophic, mixotrophic and heterotrophic species.

197 Shannon diversity index with natural log base were calculated for every sample to facilitate 198 comparisons among the spatial and temporal scales examined (Magurran, 2004). 199 Microphytoplankton community structure was analysed through the attributes richness 200 and abundance (based on the Bray-Curtis index), and composition (based on the Jaccard 201 index). Dissimilarity matrices for both indexes were constructed from the original 202 biological data matrices. Non-metric multidimensional ordination (nMDS) was performed 203 to aid the visualization of temporal patterns and spatial distributions of the samples in 204 terms of the microphytoplankton assemblage. When appropriate, centroids were used to 
205 illustrate these patterns. Null hypotheses of no differences in the abundance and 206 composition, as well as the diversity of microphytoplankton, were tested using 207 permutational multivariate analysis of variance (PER-MANOVA, Anderson, 2001). When 208 significant differences $(\mathrm{P}(\mathrm{perm})<0.05)$ were found for certain factors or interaction terms, 209 species contributing to at least $60 \%$ of the variability between levels of the terms were 210 identified using the SIMPER routine (Clark \& Warwick, 2001). Univariate ANOVAs were 211 performed on the species or taxa selected by the SIMPER routine, and a posteriori pair-wise 212 comparisons were performed between levels of the terms with p-values under a 0.05 alpha 213 value. These analyses were performed using PRIMER-E v6 software (Clarke \& Gorley, 214 2006)

\section{$215 \quad 3 . \quad$ Results}

216 A total of 100 taxa of microalgae were identified from the water samples; 91 were 217 identified for 2007, 51 for 2008 and 42 were common to both years (Supplementary 218 Material Table 1). Taking both years into account, the most abundant group were the 219 diatoms (Bacillariophyceae), which represented $62 \%$ of the microalgae, followed by 220 dinoflagellates (Dinophyceae, 25.4\%), and Cyanophytes (Cyanophyceae, 8\%). 221 Coccolithophores (Haptophytes) and Chlorophytes represented less than 5\% of the total 222 abundance. This two-year trend of group abundances hold true for all reefs in 2008, but in 223 2007, cyanophytes reached highest densities of 43 cells per $\mathrm{mL}$ at the NE reefs only (Fig. 2). 224 Most species of diatoms identified (62\% of all counted diatoms) were small (6-10 and 16$22520 \mu \mathrm{m}$ ), oceanic taxa from the genera Nitzschia, Pseudo-nitzschia, Paralia and Thalassiosira. 226 Most taxa of dinoflagellates (48\% of the counted cells) were 16-20 $\mu \mathrm{m}$ in size (Fig. 3). The 227 coccolithophores were represented only by the species Emiliana huxleyi.

228 Microphytoplankton abundance ranged between $0.26 \pm 0.06$ and $49.12 \pm 8.37$ cells per mL 229 (Mean \pm SD) across reefs, years and spawning times. Since the variability between years 230 was high (94\% of the variance explained, PERMANOVA table not shown), the 231 microphytoplankton assemblages were analyzed separately for each year to evaluate the 232 effect of the other factors examined. For both years, dissimilarity in microphytoplankton 233 abundance and composition was observed between localities (NE or solid vs. SW or empty 234 symbols in Fig. 4), however, most of the variation in assemblage structure occurred 235 between reefs, particularly in 2008 (Table 2). When considering all taxa, the 
236 microphytoplankton assemblage showed little variation in structure among time periods 237 related to coral spawning (see low variation coefficients for the interaction 238 Reef(Locality)xPeriod, Table 2). Contrasting with this weak response from the 239 microphytoplankton structure, Shannon diversity indexes differed significantly among the 240 spawning times in 2007 (Pseudo-F: 2.37, p=0.042) despite, variability between replicate 241 samples being above 60\% (Fig. 5). Taxa diversity differed between the spawning times in 242 NE reefs. At MD, there were differences Before and During spawning times (a posteriori 243 pairwise comparisons $\mathrm{t}=2.16, \mathrm{p}=0.04$ ) and at $\mathrm{GR}$, between the During and After periods $244(\mathrm{t}=1.97, \mathrm{p}=0.049)$. In 2008, diversity was similar among spawning times but varied 245 significantly among reefs as in 2007 (Pseudo-F: 10.18, p=0.001). In this case, diversity was 246 lowest at CYA, a SW site, compared with the other reefs $(t=1.56, p=0.049$, respectively; Fig. $2475)$.

248 TABLE 2. PER-MANOVA based on the Bray-Curtis dissimilarities (no transformation) of 249 the multivariate abundance of microalgae (102 taxa); on two reefs (random, nested) in the 250 Northeast and two reefs in the Southwest ("Locality", fixed) of Los Roques, during, before 251 and after ("Period", fixed) coral spawning events in 2007 (A) and 2008 (B). The same 252 results were obtained for composition (Jaccard index based PERMANOVA) but are not 253 shown.

254 (A)

\begin{tabular}{lccccc}
\multicolumn{1}{c}{ Source of Variation } & d.f. & MS & Pseudo-F & P(perm) & VC (\%) \\
\hline Locality & 1 & 20104 & 3.0056 & 0.1664 & 4.88 \\
Period & 2 & 2530.7 & 0.98108 & 0.4854 & 0.00 \\
Reef (Lo) & 2 & 6690.3 & 3.3611 & $0.0001^{*}$ & 3.42 \\
LoxPE & 2 & 2393.5 & 0.9279 & 0.5254 & 0.00 \\
Re[Lo]xPE & 4 & 2579.7 & 1.296 & 0.07 & 1.28 \\
Residuals & 240 & 1990.5 & & & 90.43 \\
Total & 251 & & & &
\end{tabular}

(B)

\begin{tabular}{lccccc} 
Source of Variation & d.f. & MS & Pseudo-F & P(perm) & VC (\%) \\
\hline Locality & 1 & 9933.6 & 1.3887 & 0.336 & 2.78 \\
Period & 2 & 501.9 & 0.79077 & 0.5737 & 0.00
\end{tabular}




$\begin{array}{lccccc}\text { Reef(Lo) } & 2 & 7153.3 & 12.299 & 0.0001^{*} & 13.14 \\ \text { LoxPE } & 2 & 501.9 & 0.79077 & 0.5724 & 0.00 \\ \text { Re[Lo]xPE } & 4 & 634.7 & 1.0912 & 0.3085 & 0.32 \\ \text { Residuals } & 276 & 581.62 & & & 83.76 \\ \text { Total } & 287 & & & & \end{array}$

256 Lo: Locality; PE: Period of spawning times; Re: Reefs; Df: Degree of freedom; MS: Mean 257 Square; VC: Variation Coefficient; P: probability of obtaining a Pseudo-F value similar to the 258 ones calculated when actually there is no difference between the levels of the factors 259 evaluated; *: P(perm) $<0.05$

260 Variations in microphytoplankton with respect to coral spawning times (Period) were 261 more evident when analyzed by higher taxonomic groups instead of all taxa. The structure 262 of diatoms, dinoflagellates and cyanophytes differed between reefs for both years, and 263 some of these assemblages differed among spawning times at specific reefs (Table 3). In 264 particular, the structure of dinoflagellates (Pseudo- $F=3.93, p=0.001$ ) and its trophic groups 265 (Pseudo-F=8.12, $\mathrm{p}=0.001$ ) differed significantly between spawning times (periods) for 266 some reefs in 2007 (Fig. 6). Also in 2007, the assemblage of cyanophytes differed After the 267 coral spawning at NE reefs (Pseudo-F=2.14, p=0.032), when the coccoid, filamentous and 268 the nostocal Anabaena sp. peaked in an episodic manner. On the other hand, the 269 oscillatorial cyanophytes Lyngbya and Spyrogira were identified only at Dos Mosquises (a 270 SW reef) on the dates of expected coral spawning. While variations in dinoflagellates and 271 cyanophytes assemblages occurred in relation to spawning times in 2007, diatoms 272 assemblage only differed spatially among reefs for both 2007 and 2008 (Pseudo-F=2.048, $273 \mathrm{p}=0.05$ and Pseudo-F=1.75, p=0.003, respectively).

274 Most of the dissimilarity in the assemblage of dinoflagellates among spawning times in 2752007 (>70\% according to the SIMPER routine) was due to variations in the presence of the 276 heterotrophic taxa Protoperidinium sp., P. thorianum, P. minutum, P. excentricum, $P$. 277 conicoides, $P$. pyriforme, and the mixotrophic species Neoceratium lineatum and Scrippsiella 278 trochoidea (Supplementary Materials Table 2). For each of these taxa, the univariate 279 PERMANOVAs showed a significant difference among spawning time periods at MD and at 280 DMS (a NE reef and a SW reef, respectively). At the SW reefs, the density of mixotrophic 281 species decreased towards the After period of the spawning times, while the heterotrophic 
282 species increased (Fig. 6). At the NE reefs, the abundance of heterotrophic species also 283 increased After the spawning, whereas the mixotrophic species showed an opposite 284 pattern to the SW reefs as it increased in abundance. This pattern within locality (NE and 285 SW) was consistent for all reefs in 2007 (Fig. 6). Correlations between the abundance of 286 trophic groups were negative and low ( $\leq 30 \%)$, with the exception of mixotrophic and 287 obligate autotrophs dinoflagellates (64.3\%), although this was not statistically significant. 288 In 2008, dinoflagellates as well as its trophic groups differed only at reefs scales (i.e. GR, 289 MD, CYA, DMS), since 95\% of their abundances occurred at the NE reefs where mixotrophic 290 species peaked (Fig. 6).

291 292 293 294 295

TABLE 3. Statistically significant $(\mathrm{p}<0.05)$ results from the PER-MANOVA analysis, based on the Bray-Curtis dissimilarities (no transformation) of the univariate abundance of microalgae taxonomic and trophic groups; on two reefs (random, nested) in the Northeast and two reef in the Southwest ("Locality", fixed) of Los Roques, during, before and after ("Period", fixed) coral spawning events in 2007 and 2008.

\begin{tabular}{|c|c|c|c|c|c|}
\hline & $\begin{array}{l}\text { Source of } \\
\text { Variation }\end{array}$ & Diatoms & Dinoflagellates & DTG & Cyanophytes \\
\hline \multirow{5}{*}{ } & Locality (Lo) & & & & \\
\hline & Period (PE) & & * & * & \\
\hline & Reef[Lo] & * & & & \\
\hline & LoxPe & & & & \\
\hline & $\mathrm{Re}[\mathrm{Lo}] \mathrm{xPe}$ & & * & * & * \\
\hline \multirow{5}{*}{$\begin{array}{l}\infty \\
\stackrel{ }{0} \\
\end{array}$} & Locality (Lo) & & & & \\
\hline & Period (PE) & & & & \\
\hline & Reef[Lo] & * & $*$ & & \\
\hline & LoxPe & & & & \\
\hline & $\mathrm{Re}[\mathrm{Lo}] \times \mathrm{Pe}$ & & & & \\
\hline
\end{tabular}

297 For diatoms, more than $98 \%$ of the dissimilarity between the reefs in both years (SIMPER 298 analysis) was due to variation in the presence and abundance of Aptinoptychus sp., 299 Aulacoseria, Cerataulina pelagica, Thalassiosira subtilis, Rhizosolenia imbricata and Melosira 300 varians. In 2007, significant differences on the abundance of C. pelagica, T. subtilis and $R$. 
301 imbricata occurred between reefs and between periods for $R$. imbricata and C. pelagica on

302 SW reefs. Cerataulina pelagica was more abundant in the SW reefs, whereas T. subtilis was 303 only identified on NE reefs. Significant correlations between the abundance of these 304 diatoms and dinoflagellates trophic groups were found for SW reefs. Here, in 2007, $C$. 305 pelagica abundance was negatively and weakly correlated ( $\mathrm{r} 2=-0.24 ; \mathrm{p}=0.055)$ with that of 306 the mixotrophic dinoflagellate Scripsiella trochoidea, and positively correlated with that of 307 heterotrophic dinoflagellates of the genus Protoperidinium (r2=0.77; p=0.0002; Fig. 7). On 308 the contrary, $R$. imbricata abundance decreased and was negatively correlated (r2=-0.53; $309 \mathrm{p}=0.00056$ ) with the abundance of the heterotrophic Protoperidinium species (Fig. 7). In NE 310 reefs, none of the abundances of Thalassiosira subtilis, Cerataulina pelagica or Rhizosolenia 311 imbricata were correlated to that of dinoflagellates trophic groups.

312 Chlorophyll $a$ concentrations ranged between 0.35 and $1.03 \mathrm{mg} / \mathrm{m}^{3}$ in 2007 and between 3130.039 and $1.3 \mathrm{mg} / \mathrm{m}^{3}$ in 2008 . These concentrations increased in days corresponding to the 314 During and After spawning times, consistently for both years and for all reefs when data 315 was available (Table 4a). Also, chlorophyll concentrations were more variable in 2008 than 316 in 2007, and in the SW than in NE reefs for both years (Fig. 8). Sea surface temperatures 317 ranged between 26.45 and $29.04{ }^{\circ} \mathrm{C}$ in 2007 and between 27.4 and $29.1{ }^{\circ} \mathrm{C}$ in 2008 (Table 318 4b). In 2007, SST increased through the sampling period in all reefs but showing a larger 319 variability in the SW reefs (Fig. 9). In contrast, SST values were very similar among reefs in 320 2008, reaching higher temperatures During spawning time and decreasing by day 9 within 321 the After spawning time (Fig. 9).

322 TABLE 4. A) Chlorophyll $a$ concentration $\left(\mathrm{mg} / \mathrm{m}^{3}\right)$ and B) Seawater Surface Temperature $323(\stackrel{\circ}{\circ})$ for 9 consecutive days, "Before", "During" and "After" the expected spawning dates for 324 southern Caribbean acroporids. Data obtained from remote sensing (MODIS SCAR; $3251 \mathrm{kmx} 1 \mathrm{~km}$ resolution).

(A)

\begin{tabular}{c|cccc|cccc}
\multicolumn{7}{c}{2007} & \multicolumn{5}{c}{2008} \\
Periods & Days & NE (MD-GR) & CYA & DMS & Days & NE (MD-GR) & CYA & DMS \\
\hline \multirow{3}{*}{ Before } & 28 -Aug & NA & NA & NA & 16 -Aug & 0.61 & 0.039 & NA \\
& 29-Aug & 0.631 & 0.387 & 0.903 & $17-A u g$ & 0.602 & 0.042 & 0.075 \\
& 30-Aug & 0.67 & 0.35 & NA & 18-Aug & NA & 0.0545 & 0.0544 \\
\hline
\end{tabular}




\begin{tabular}{l|cccc|cccc}
\hline \multirow{4}{*}{ During } & 31-Aug & 0.73 & 0.42 & NA & 19-Aug & 0.943 & 0.19 & 0.23 \\
& 01-Sep & NA & NA & NA & 20-Aug & 0.903 & 0.280 & 1.076 \\
& 02-Sep & 1.03 & 0.58 & NA & 21-Aug & 0.87 & NA & NA \\
\hline \multirow{4}{*}{ After } & 03-Sep & 0.850 & 0.643 & 1.040 & 22-Aug & 0.77 & 0.60 & 1.08 \\
& 04-Sep & NA & NA & NA & 23-Aug & 1.23 & 0.43 & 1.24 \\
& 05-Sep & 0.651 & 0.431 & 0.826 & 24-Aug & 1.30 & NA & NA
\end{tabular}

(B)

2007

\begin{tabular}{|c|c|c|c|c|c|c|c|c|}
\hline Periods & Days & NE (MD-GR) & CYA & DMS & Days & NE (MD-GR) & CYA & DMS \\
\hline \multirow{3}{*}{ Before } & 28-Aug & 27.57 & 27.57 & 27.07 & 16-Aug & NA & NA & NA \\
\hline & 29-Aug & 27.87 & 27.87 & 28.23 & 17-Aug & 27.60 & 27.60 & 27.98 \\
\hline & 30-Aug & 27.72 & 27.72 & 28.09 & 18-Aug & 27.41 & 27.41 & 27.54 \\
\hline \multirow{3}{*}{ During } & 31-Aug & 27.65 & 27.65 & 26.45 & 19-Aug & 28.91 & 28.91 & 29.15 \\
\hline & 01-Sep & 27.82 & 27.82 & 28.92 & 20-Aug & 28.27 & 28.27 & 28.22 \\
\hline & 02-Sep & 27.94 & 27.94 & 29.04 & 21-Aug & 29.01 & 29.01 & 28.67 \\
\hline \multirow{3}{*}{ After } & 03-Sep & 28.40 & 28.40 & 29.03 & 22-Aug & 28.13 & 28.13 & 27.96 \\
\hline & 04-Sep & 28.65 & 28.65 & 28.85 & 23-Aug & 27.95 & 27.95 & 28.01 \\
\hline & 05-Sep & 28.90 & 28.90 & 28.93 & 24-Aug & NA & NA & NA \\
\hline
\end{tabular}

\section{4. Discussion}

328 Expected variations in microphytoplankton abundance and composition linked to the coral 329 spawning events were mostly overridden by variations between years and spatial 330 variations among reefs in Los Roques archipelago. However, when groups of the 331 microphytoplankton were examined, dinoflagellate assemblages and trophic functional 332 groups varied in relation to the spawning times. Heterotrophic dinoflagellates increased in 333 abundance after the spawning event in 2007 for some reefs, while in 2008 this increment 334 only occurred for mixotrophic dinoflagellates in one reef. Also, diatoms Cerataulina 335 pelagica and Rhizosolenia imbricata varied simultaneously in abundance, suggesting that 336 they may be responding to re-mineralization of dissolved nitrogen and grazing activity, 337 respectively. These results suggest an important role of microheterotrophic grazers in re338 mineralization of organic matter in coral reef waters. Also, our findings support the 339 relevance of assessing compositional changes of larger size fractions of the phytoplankton 340 when evaluating primary productivity and nutrient fluxes. A lack of direct measurements 341 from the nutrient flux-cycling and benthic-pelagic coupling in our study, hampers an in- 
342 depth discussion of the patterns observed; however, changes that occurred in a few days 343 on the composition and abundance of some taxa of the microphytoplanktonic groups 344 examined were likely related to macronutrient inputs that resulted from coral spawning, as 345 supported by concurrent increases in clorophyll $a$ concentrations obtained by satellite 346 images.

347 Contrasting results among studies support that phyto- and bacterioplankton and nutrient 348 flux responses to coral spawning are variable across coral reef regions. The subtle changes 349 in microphytoplankton at the lowest taxonomic level observed at Los Roques in relation to 350 coral spawning, contrasted with studies from other regions (Wild et al., 2004; Eyre et al., 351 2008; Glud et al., 2008; Horne, 2011). In the Great Barrier Reef (GBR), Australia and the 352 Gulf of Mexico, both planktonic and benthic microalgae blooms had been observed within 353 2-5 days following a mass coral spawning event (Wild et al., 2004; Eyre et al., 2008; Glud et 354 al., 2008; Horne, 2011). At Los Roques, chlorophyll $a$ concentrations increased During and 355 After the spawning times in all reefs, however, only the abundance and composition of 356 dinoflagellates and cyanophyte assemblages varied with spawning times. Furthermore, 357 changes in cyanophytes consisted of a freshwater taxon that spiked in abundance in 2007, 358 likely due to anthropogenic influence in the NE reefs rather than to a response from spawn 359 material. Also, increased chlorophyll $a$ concentrations in relation to spawning in Los 360 Roques was lower than that reported for the GBR (Glud et al., 2008). Differences in the 361 magnitude (e.g. spawned material, number of species and geographic scale) of the 362 spawning events influence the amount of organic matter released to the water column, and 363 thus affect regional differences, which support the uniqueness of the mass coral spawning 364 event at the GBR compared to that occurring in other regions (Harrison \& Booth, 2007; 365 Mangubhai \& Harrison, 2008). This might explain why in Los Roques and other coral reefs 366 (Apprill \& Rappé, 2011), phytoplankton blooms were not detected after massive coral 367 spawning events.

368 In addition to the intensity and magnitude of spawning events across regions, other factors 369 might influence the variability in the phytoplankton response. In this study, the sampling 370 days within spawning periods (Before, During and After) were established based on 371 expected spawning dates for Acropora palmata, as this species marks the beginning of the 372 multi-specific coral spawning event in Caribbean shallow waters. However, variations in 
373 spawning intensity and time, as reported for this coral species (unpublished data by Miller 374 \& Szmant in Key Largo, Florida and La Parguera, Puerto Rico in 2000, Japp between the 375 1970s and 1980s and Miller in 2001), are likely to affect the observed response of 376 microphytoplankton assemblages between years and among spawning periods. In 377 particular, Acropora palmata larval abundance suggested a late start in spawning for most 378 reefs in 2008 (i.e. +5 days instead of $+2-3$ days, supplementary material Table 3 ). The 379 abundance of Acropora palmata larvae in the plankton at the time of this study (Zubillaga, 380 2010) strongly suggested that coral spawning at Los Roques was larger in 2008 than in 381 2007, but in 2008 it lagged with respect to our sampling periods in most of the reefs 382 (supplementary material Table 3). This would have resulted in a During period being 383 similar to a Before period, both with little spawn material; explaining the differences in 384 composition and abundance of microphytoplankton observed between 2007 and 2008 and 385 the observed increase in abundance of diatoms and chlorophyll $a$ concentration at one of 386 the SW reefs only in 2008. Days and reefs with higher abundance of coral larvae (Zubillaga, 387 2010) coincided with diatoms being more abundant, a group that requires higher inorganic 388 389 390 391 in these trophic groups, favouring heterotrophy.

392 A clear pattern of the role of microheterotrophy in the microphytoplankton response to 393 larvae abundance, as it has been reported for phytoplankton biomass and primary 394 productivity (Eyre et al., 2008; Glud et al., 2008), was apparently hidden by the high 395 variability observed among reefs. Previous work in which biomass, primary productivity 396 and/or respiration in sediment and water have peaked shortly after the release of spawned 397 material (Eyre et al., 2008; Glud et al., 2008) were carried out only at one site, on a reef flat. 398 Thus, an examination of these processes (i.e. phytoplankton primary production, biomass 399 and species composition in relation to nutrient re-mineralization) at larger spatial scales in 400 reefs might yield large variability as it was found in this study.

401 In addition to the amount of material spawned, other local (reef) scale-dependent 402 processes such as re-mineralization of organic matter, might be related to the variations in 403 chla and microphytoplankton observed among reefs in nine days. The response of 
404 photosynthetic microalgae to the input of labile organic compounds is mediated by the 405 metabolic activity of the microbial reef community, often called the microbial loop 406 (Anderson \& Ducklow, 2001; Pomeroy et al., 2007; Nelson et al., 2013). This process entails 407 great variability as it may operate on time scales of hours to days (Carlson, 2002) and it 408 depends on many factors, from benthic composition to oceanographic characteristics of the 409 reefs (Nelson et al., 2011). Re-mineralization of coral spawn materials is mostly carried out 410 in reef sediments (Westneat \& Resing, 1988; Haas et al., 2011, 2013), whereas the role 411 played by bacterioplankton in the process vary from immediate and significant (Wild et al., 412 2008) to lagged and marginal (Apprill \& Rappé, 2011). Thus, the temporal response of the 413 microphytoplankton community to an organic matter input might be controlled by how 414 fast the re-mineralized material is incorporated into the water column through benthic415 pelagic coupling (Eyre et al., 2008; Patten et al., 2008; Nelson et al., 2011; Apprill \& Rappé, 416 2011). In this sense, during coral spawning events in the Gulf of Mexico, Horne (2011) 417 observed only small changes of nutrient concentrations in water, which suggests a low re418 mineralization activity in the water column, but he also reported an increased abundance 419 of dinoflagellates of the genus Ceratium spp. Thus, in our study, reef-specific differences in 420 the re-mineralization activity could have contributed towards the variability found at the 421 reef scale in the structure of diatoms assemblages.

422 In this study, functional group and species-specific patterns of microphytoplankton related 423 to the spawning period were observed at some reefs. During and After the coral spawning 424 in 2007, the increased abundance in Protoperidinium heterotrophic species, and the 425 concomitant decrease of the mixotrophic Neoceratium lineatum, may constitute a response 426 to the coral spawning via abundance of prey. The abundance of heterotrophic 427 dinoflagellates found in this study was very similar to that found by Horne (2011) in the 428 Gulf of Mexico 2 days after the coral spawning. However, at some reefs in Los Roques, the 429 abundance of mixotrophic dinoflagellates was almost double that reported by Horne 430 (2011). Some heterotrophic dinoflagellate species prey preferentially upon heterotrophic 431 bacteria and protozoans and the eggs and larvae of metazoans (Jeong, 1994, 2007, et al., 432 2010), whereas mixotrophic species more frequently prey upon small-size microalgae like 433 haptophytes, crysophytes, picophytes, raphidophytes (not assessed on this study), 434 chlorophytes, autotrophic dinoflagellates, some diatom species and autotrophic bacteria (Li 
435 et al., 2000; Jeong et al., 2005; Berge et al., 2008). The negative correlation between the 436 abundance of heterotrophic dinoflagellates and one of their grazed species, the diatom 437 Rhizosolenia imbricata (Willén, 1991), might indicate that preferential feeding occurred in 438 detriment of autotrophic microalgae species. Consistent with this, heterotrophic and 439 mixotrophic dinoflagellates are recognized to have important effects on plankton 440 abundance and composition as microheterotrophic grazers (Lessard \& Swift, 1985). Thus, 441 despite increased Chla concentrations, grazing activity by heterotrophic dinoflagellates 442 might explain the lack of a significant increase in diatom abundance in relation to spawning 443 periods at some reefs in 2007.

444 In addition to grazing, microheterotrophic phytoplankton (i.e. mixo- and heterotrophic 445 dinoflagellates among other protozoans) maintain nutrient demand through re446 mineralization of organic matter in oceanic waters year-round, and their contribution to 447 dissolved inorganic nutrients might be higher than that of zooplankton (Bode et al., 2005). 448 Oligotrophic coral reefs have an efficient recycling of nutrients (Szmant, 2002; Wild et al., 449 2008) and are able to incorporate a massive coral-spawning organic matter input in less 450 than 6 days through the benthic microbial loop. Because sediment re-mineralized nitrogen 451 is not readily returned to the water column (Eyre et al., 2008), microheterotrophic re452 mineralization within the microphytoplankton community might be mediating the 453 response of autotrophic groups to the input of that organic matter. Although the role of 454 these grazers in the re-mineralization of spawned materials in coral reefs has not been 455 evaluated, the positive correlation between the diatom Cerataulina pelagica - whose 456 abundance has been related to increase on dissolved nitrate and ammonium availability in 457 the water column (Härnström et al., 2009) - and the heterotrophic dinoflagellates of the 458 genus Protoperidinium, might suggest an important role of the latter on the availability of 459 dissolved inorganic nutrients at the SW reefs. A similar increase in dinoflagellate 460 abundance coinciding with a decrease in that of the diatoms was found 2 days after coral 461 spawning in the Gulf of Mexico (Horne, 2011).

462 At Los Roques, high abundance of small rather than medium and large size diatoms, 463 especially in the relatively pristine SW reefs, might indicate an effective nutrient cycling as 464 cell size in microalgae has an influence on nutrient preference and uptake (Koiko et al., 465 1985; Stolte et al., 1994), with smaller phytoplankters favoured over larger ones in systems 
466 driven by regenerated nutrients and rapid cycling of organic matter (Caroppo, 2000). 467 Similarly, the peak abundance in diatoms coinciding with that of mixotrophic 468 dinoflagellates in 2008 at GR might also respond to re-mineralization of spawned materials 469 by the latter. However, the consistency of this pattern was not captured in our 2008 470 sampling probably due to lagged spawn in the other reefs. Also, sampling days for each 471 time period (i.e. Before-During-After) were relatively short (3 days each), and these 472 spawning periods were contiguous. If the response of the larger size phototrophs of the 473 phytoplankton to spawned organic matter is mediated by microheterotrophy, as suggested 474 by our results, more days between sampling periods could have been better for detecting 475 changes in the microphytoplankton assemblages. .

476 Observed microphytoplankton density, although well within previous reports for Dos 477 Mosquises in Los Roques and other oligotrophic waters (e.g. González, 1989; Spiniello, 478 1996, Madera \& Furderer, 1997), revealed spatiotemporal differences of the 479 microphytoplankton community in Los Roques at scales previously unexplored. 480 Differences in plankton assemblages known to occur between the NE and SW sectors of the 481 archipelago during the dry season from November to June (González, 1989; Casanova et al., 482 2007) also hold true for August and September during this study, a period with a weak 483 hydrodynamic influence in the area (Casanova et al., 2007). Our results also indicated a 484 strong reef-based variability within previously thought homogenous sectors (Casanova et 485 al., 2007) and a daily variability within otherwise considered constant seasons (González, 486 1989, Spiniello, 1996; Madera \& Furderer, 1997). The presence of the cyanophyte 487 Anabaena sp. in August and September on the NE reefs in 2007 constitutes the first report 488 of this species in Los Roques, indicating episodic freshwater inputs, consistent with human 489 settlement at Gran Roque. Algae from this genus can produce toxins of public health 490 concern (Figuereido et al., 2004); however, their disappearance in samples from 491 consecutive days suggests unfavourable water conditions for these populations and/or 492 short water residence time. Toxin-producing dinoflagellate species were also identified, but 493 in low abundance.

494 While our study lacked of direct biomass measures through time, studies elsewhere have 495 not targeted compositional changes on microalgae assemblages. Therefore, a full picture of 496 changes in phytoplankton across regions and reefs in relation to coral spawning is still 
497 lacking. Our results highlighted the importance of including taxonomical and functional 498 changes in larger size phytoplankton fractions when evaluating nutrient fluxes and primary 499 and secondary pelagic productivity in coral reefs in relation to coral spawning events, as 500 well as the importance of replication at reef spatial scales for generalizing observed 501 patterns. Manipulative experiments to establish the effect of microheterotrophic grazing 502 and nutrient re-mineralization activity by dinoflagellates on the response of the 503 phytoplankton assemblages to organic matter inputs constitute a logical next step to better 504 comprehend the role of dinoflagellates in reef waters during a nutrient input. 505 Concomitantly, specific processes related to inter-annual variability need to be assessed 506 through the sampling of non-spawning times as well in order to better discriminate 507 phytoplankton responses to coral spawning events. Similarly, large-scale operating 508 oceanographic and/or climatic processes not yet assessed on the study site may also have 509 an important role as structuring factors, as suggested by the amount of inter-annual 510 variability observed in the microphytoplankton structure and composition and the daily 511 patterns of SST and Chla concentrations.

512 This study evaluated the structure of larger size fractions of the phytoplankton during coral 513 spawning for the first time in the Caribbean, showing variations in dinoflagellate 514 assemblages and its trophic groups, as well as in some diatom species. These variations 515 highlighted the potential impact of heterotrophic dinoflagellates on coral reefs primary 516 productivity and organic matter cycling. Thus, by examining the structure of 517 microphytoplankton at multiple spatiotemporal scales in Los Roques archipelago, this 518 study provides a first approximation of the effect of coral spawning on these assemblages.

\section{5. Acknowledgement}

520 The authors would like to thank Alejandra Hernández, Adriana Humanes, Sebastián

521 Rodríguez, Denise Debrot, María Isabel Reyes, Helios Martínez, Melanie Van Solt, Julie 522 Pérez, Aldo Cróquer, Federico Pisani, Julia Dávila and the staff of Fundación Científica Los 523 Roques for the help during the samplings. Also, Professor Juan José Cruz for the help 524 provided with equipment.

\section{$5256 . \quad$ References}

526 Anderson, M. J. 2001. A new method for non-parametric multivariate analysis of variance. 
528 Anderson, T. R., \& Ducklow, H. W. 2001. Microbial loop carbon cycling in ocean environments 529 studied using a simple steady-state model. Aquatic Microbial Ecology, 26(1), 37-49.

530

531

532

533

534

535

536

537

538

539

540

541

542

543

544

545

546

547

548

549

550

551

552

553

554

555

556

557

558 doi:10.3354/ame026037

Apprill, A., \& Rappé, M. S. 2011. Response of the microbial community to coral spawning in lagoon and reef flat environments of Hawaii, USA. Aquatic Microbial Ecology, 62(3), 251-266. doi:10.3354/ame01471

De Figueiredo, D. R., Azeiteiro, U. M., Esteves, S. M., Gonçalves, F. J. M., \& Pereira, M. J. 2004. Microcystin-producing blooms - a serious global public health issue. Ecotoxicology and Environmental Safety, 59(2), 151-163. doi:10.1016/j.ecoenv.2004.04.006

Bak, R. P. M., \& Engel, M. S. 1979. Distribution, abundance and survival of juvenile hermatypic corals (Scleractinia) and the importance of life history strategies in the parent coral community. Marine Biology, 54(4), 341-352. doi:10.1007/BF00395440

Barott, K. L., Williams, G. J., Vermeij, M. J. A., Harris, J., Smith, J. E., Rohwer, F. L., \& Sandin, S. A. 2012. FEATURE ARTICLE Natural history of coral-algae competition across a gradient of human activity in the Line Islands. Marine Ecology Progress Series, 460, 1-12. doi:10.3354/meps09874

Bassim, K., Sammarco, P., \& Snell, T. 2002. Effects of temperature on success of (self and nonself) fertilization and embryogenesis in Diploria strigosa (Cnidaria, Scleractinia). Marine Biology, 140(3), 479-488. doi:10.1007/s00227-001-0722-4

Bastidas, C., Bone, D., Croquer, A., Debrot, D., Garcia, E., Humanes, A., Ramos, R. \& Rodríguez, S. 2012. Massive hard coral loss after a severe bleaching event in 2010 at Los Roques, Venezuela. Revista de Biología Tropical, 60, 29-37.

Bastidas, C., Cróquer, A., Zubillaga, A. L., Ramos, R., Kortnik, V., Weinberger, C., \& Márquez, L. M. 2005. Coral mass- and split-spawning at a coastal and an offshore Venezuelan reefs, southern Caribbean. Hydrobiologia, 541(1), 101-106. doi:10.1007/s10750-004-4672-y

Beaver, C. R., Earle, S. A., Evans, E. F. (Kip), Cerda, A. V. de la, \& Jr, J. W. T. 2004. Mass spawning of reef corals within the Veracruz Reef System, Veracruz, Mexico. Coral Reefs, 23(3), 324-324. doi:10.1007/s00338-004-0373-2

Bérard-Therriault, L., Poulin, M., \& Bossé, L. 1999. Guide d'identification du phytoplancton marin de l'estuaire et du Golfe du Saint-Laurent incluant également certains protozoaires, 387 pp. Publication Spéciale Canadienne des Sciences Halieutiques et Aquatiques. 
559 Berge, T., Hansen, P. J., \& Moestrup, Ø. 2008. Feeding mechanism, prey specificity and growth

560

561

562

563

564

565

566

567

568

569

570

571

572

573

574

575

576

577

578

579

580

581

582

583

584

585

586

587

588 in light and dark of the plastidic dinoflagellate Karlodinium armiger. Aquatic Microbial Ecology, 50(3), 279-288.

Bode, A., Barquero, S., Varela, M., Braun, J. G., \& De Armas, D. 2001. Pelagic bacteria and phytoplankton in oceanic waters near the Canary Islands in summer. Marine Ecology Progress Series 209, 1-17.

Bode, A., Barquero, S., González, N., Alvarez-Ossorio, M. T., \& Varela, M. 2004. Contribution of heterotrophic plankton to nitrogen regeneration in the upwelling ecosystem of A Coruña (NW Spain). Journal of Plankton Research. 26, 11-28. doi:10.1093/plankt/fbh003.

Brooke, S., \& Young, C. M. 2003. Reproductive ecology of a deep-water scleractinian coral, Oculina varicosa, from the southeast Florida shelf. Continental Shelf Research, 23(9), 847-858. doi:10.1016/S0278-4343(03)00080-3

Budd, A. F. 1990. Longterm Patterns of Morphological Variation within and Among Species of Reef-Corals and their Relationship to Sexual reproduction. Systematic Botany, 15(1), 150165.

Burke, L., Reytar, K., Spalding, M., \& Perry, A. 2011. Reefs at Risk Revisited. Available at: http://www.wri.org/publication/reefs-risk-revisited

Carlon, D. B. 2002. Production and supply of larvae as determinants of zonation in a brooding tropical coral. Journal of Experimental Marine Biology and Ecology, 268(1), 33-46. doi:10.1016/S0022-0981(01)00369-0

Carlon, D. B., \& Olson, R.R. 1993. Larval dispersal distance as an explanation for adult spatial pattern in two Caribbean reef corals. Journal Experimental Marine Biology and Ecology 173:247-263. doi:10.1016/0022-0981(93)90056-T

Caroppo, C. 2000. The contribution of picophytoplankton to community structure in a Mediterranean brackish environment. Journal of Plankton Research, 22(2), 381-397. doi:10.1093/plankt/22.2.381

Casanova, E., Zoppy, E., \& Montiel, E. 2007. Caracterización espacial y temporal del zooplancton en el archipiélago los roques, Venezuela. Boletín del Instituto Oceanográfico $\begin{array}{llll}\text { de } & \text { Venezuela, } & \text { 46(1). } & \text { Retrieved }\end{array}$ http://www.ojs.udo.edu.ve/index.php/boletiniov/article/view/764 
589 Casas, B., Varela, M., Canle, M., González, N., \& Bode, A. 1997. Seasonal Variations of 590 Nutrients, Seston and Phytoplankton, and Upwelling Intensity off La Coruña (NW Spain). 591 Estuarine, Coastal and Shelf Science 44, 767-778. doi:10.1006/ecss.1996.0155.

592 Clarke, KR, Gorley, RN, 2006. PRIMER v6: User Manual/Tutorial. PRIMER-E, Plymouth, $593 \quad 192 \mathrm{pp}$.

594 Ceh, J., Raina, J.-B., Soo, R. M., van Keulen, M., \& Bourne, D. G. 2012. Coral-Bacterial 595 Communities before and after a Coral Mass Spawning Event on Ningaloo Reef. PLoS 596 ONE, 7(5), e36920. doi:10.1371/journal.pone.0036920

597 Charpy-Roubaud, C. J., Charpy, L., \& Cremoux, J. L. 1990. Nutrient budget of the lagoonal 598 waters in an open central South Pacific atoll (Tikehau, Tuamotu, French Polynesia). 599 Marine Biology, 107(1), 67-73. doi:10.1007/BF01313243

600 Clarke, K., \& Warwick, R.M. 2001. Change in Marine Communities: AN Approach to Statistical 601 Analysis and Interpretation. Plymouth, UK.

602 Coffroth, M. A., \& Mulawka, J. M. III. 1995. Identification of marine invertebrate larvae by 603 means of PCR-RAPD species-specific markers. Limnology and Oceanography 40:181604 189. doi: 10.4319/1o.1995.40.1.0181

605

Coupel, P., Matsuoka, A., Ruiz-Pino, D., Gosselin, M., Claustre, H., Marie, D., Tremblay, J.É., 606 607 \& Babin, M. 2014. Pigment signatures of phytoplankton communities in the Beaufort Sea.

608 Crosbie, N. D., \& Furnas, M. J. 2001. Net growth rates of picocyanobacteria and nanoBiogeosciences Discussions, 11, 14489-14530. 609 /microphytoplankton inhabiting shelf waters of the central $\left(17^{\circ} \mathrm{S}\right)$ and southern $\left(20^{\circ} \mathrm{S}\right)$ 610 Great Barrier Reef. Aquatic Microbial Ecology 24, 209-224. doi:10.3354/ame024209.

Cupp, E. E. 1943. Marine Plankton Diatoms of the West Coast of North America. Scripps 613 Institution of Oceanography. Available at: http://escholarship.org/uc/item/922945w8 [Accessed August 14, 2015].

615 616

Delesalle, B., Pichon, M., Frankignoulle, M., \& Gattuso, J.-P. 1993. Effects of a cyclone on coral reef phytoplankton biomass, primary production and composition (Moorea Island, French Polynesia). Journal of Plankton Research. 15, 1413-1423. doi:10.1093/plankt/15.12.1413.

Díaz-Ramos, J. R. 2000. Indice de la microflora marina de Venezuela: diatomeas, dinoflagelados y cocolitofóridos. Revista de Biología Tropical, 48(4), 897-918. 
619 Dizon, R. M., \& Yap, H. T. 1999. Short-term responses of coral reef microphytobenthic

620

621

622

623

624

625

626

627

628

629

630

631

632

633

634

635

636

637

638

639

640

641

642

643

644

645

646

647

648

649 communities to inorganic nutrient loading. Limnology and Oceanography, 44(5), 12591267. doi:10.4319/1o.1999.44.5.1259

Du Yoo, Y., Jeong, H. J., Kim, M. S., Kang, N. S., Song, J. Y., Shin, W., Young Kim, K., \& Kitack, K. 2009. Feeding by Phototrophic Red-Tide Dinoflagellates on the Ubiquitous Marine Diatom Skeletonema costatum. Journal of Eukaryotic Microbiology 56, 413-420. doi:10.1111/j.1550-7408.2009.00421.x.

Eyre, B. D., Glud, R. N., \& Patten, N. 2008. Mass coral spawning: A natural large-scale nutrient addition experiment. Limnology and Oceanography, 53(3), 997-1013. doi:10.4319/1o.2008.53.3.0997.

Fabricius, K. E., Cséke, S., Humphrey, C., \& De’ath, G. 2013. Does Trophic Status Enhance or Reduce the Thermal Tolerance of Scleractinian Corals? A Review, Experiment and Conceptual Framework. PLoS ONE 8, e54399. doi:10.1371/journal.pone.0054399.

Fadlallah, Y. H. 1983. Sexual reproduction, development and larval biology in scleractinian corals. Coral Reefs, 2(3), 129-150. doi:10.1007/BF00336720

Ferguson Wood, E. J. 1968. Studies of Phytoplankton Ecology in Tropical and Subtropical Environments of the Atlantic Ocean. Part 3. Phytoplankton Communities in the Providence Channels and the Tongue of the Ocean. Bulletin of Marine Science 18, 481-543.

Furnas, M. J., \& Mitchell, A. W. 1986. Phytoplankton dynamics in the central Great Barrier Reef-I. Seasonal changes in biomass and community structure and their relation to intrusive activity. Continental Shelf Research 6, $363-384$. doi:http://dx.doi.org/10.1016/0278-4343(86)90078-6.

Furnas, M. J., Mitchell, A. W., Gilmartin, M., \& Revelante, N. 1990. Phytoplankton biomass and primary production in semi-enclosed reef lagoons of the central Great Barrier Reef, Australia. Coral Reefs, 9(1), 1-10. doi:10.1007/BF00686716

Furnas, M. J. 1991. Net in situ growth rates of phytoplankton in an oligotrophic, tropical shelf ecosystem. Limnology and Oceanography 36, 13-29.

Furnas, M.J., Mitchell, A.W. \& Skuza, M.S. 1997. Shelf-scale nitrogen and phosphorus budgets in the central Great Barrier Reef (16-19oS). 1: 809-814. Proceedings of the 8th International Coral Reef Symposium, Panama, 24-29 June 1996. Smithsonian Tropical Research Institute 
650 Furnas, M. M., \& Mitchell, A. A. 1997. Biological oceanography of the Great Barrier Reef. In

651

652

653

654

655

656

657

658

659

660

661

662

663

664

665

666

667

668

669

670

671

672

673

674

675

676

677

678

679

The Great Barrier Reef: Science, Use and Management: A National Conference. Proceedings. 25-29 November 1996 James Cook University of North Queensland, Townsville, Queensland, Australia-pages: 1: 75-87. Great Barrier Reef Marine Park Authority \& CRC Reef Research.

Furnas, M., Mitchell, A., Skuza, M., \& Brodie, J. 2005. In the other 90\%: phytoplankton responses to enhanced nutrient availability in the Great Barrier Reef Lagoon. Marine Pollution Bulletin 51, 253 - 265. doi:http://dx.doi.org/10.1016/j.marpolbul.2004.11.010.

Garland, E.D., \& Zimmer, C.A. 2002. Hourly variations in planktonic larval distributions on the inner shelf: Emerging patterns and processes. Journal of Marine Research 60: 311-325. http://dx.doi.org/10.1357/00222400260497507

Glud, R. N., Eyre, B. D., \& Patten, N. 2008. Biogeochemical responses to mass coral spawning at the Great Barrier Reef: Effects on respiration and primary production. Limnology and Oceanography, 53(3), 1014-1024. doi:10.4319/1o.2008.53.3.1014

González, E. 1989. Producción Primaria del Fitoplancton y Caracterización Físico-química de las Aguas del Cayo Dos Mosquises, Los Roques, Venezuela. Boletín Del Instituto Oceanográfico de Venezuela, 28(1 \& 2), 35-45.

Haas, A. F., Nelson, C. E., Wegley K. L., Carlson, C. A., Rohwer, F., Leichter, J. J.,Wyatt, A., \& Smith, J. 2011. Effects of Coral Reef Benthic Primary Producers on Dissolved Organic Carbon and Microbial Activity. PLoS ONE 6, e27973. doi:10.1371/journal.pone.0027973.

Haas, A. F., Nelson, C. E., Rohwer, F., Wegley-Kelly, L., Quistad, S. D., Carlson, C. A., Leichter, J., Hatay, M., \& Smith, J. 2013. Influence of coral and algal exudates on microbially mediated reef metabolism. PeerJ 1, e108. doi:10.7717/peerj.108.

Harrison, P., \& Booth, D. 2007. Coral Reefs: naturally dynamic and increasingly disturbed ecosystems. Retrieved from http://epress.lib.uts.edu.au/research/handle/10453/7830.

Harris, G. 2012. Phytoplankton ecology: structure, function and fluctuation. Springer Science \& Business Media.

Härnström, K., Karunasagar, I., \& Godhe, A. 2009. Phytoplankton species assemblages and their relationship to hydrographic factors-a study at the old port in Mangalore, coastal Arabian Sea. Indian Journal of Marine Sciences 38, 224-234. 
680 Hasle, G.R. 1978. The Inverted-microscope Method. United Nations Educational, Scientific and 681 Cultural Organization. 337 pp.

682

683

684

685

686

687

688

689

690

691

692

693

694

695

696

697

698

699

700

701

702

703

704

705

706

707

708

Hauss, H. 2012. Pelagic community responses to changes in N: P stoichiometry in the Eastern Tropical Atlantic and Pacific. Available at: http://eprints.ifm-geomar.de/20102/

Heil, C. A., Chaston, K., Jones, A., Bird, P., Longstaff, B., Costanzo, S., \& Dennison, W. C. 2004. Benthic microalgae in coral reef sediments of the southern Great Barrier Reef, Australia. Coral Reefs, 23(3), 336-343. doi:10.1007/s00338-004-0390-1

Hoegh-Gludberg, O., Mumby, P. J., Hooten, A. J., Steneck, R. S., Greenfield, P., Gomez, E., Harvell, C.D., Sale, P., Edwards, A.J., Caldeira, K., Knowlton, N., Eakin, C.M., IglesiasProeto, R, Muthiga, N., Bradbury, R.H., Dubi, A., \& Hatziolos, M. E. 2007. Coral Reefs Under Rapid Climate Change and Ocean Acidification. Science, 318(5857), 1737-1742. doi:10.1126/science.1152509

Horne, C. L. 2012. Phytoplankton Responses to Mass Coral Spawning in the Flower Garden Banks, Gulf of Mexico. Texas A\&M University. USA. 73 pp.

Howarth, R. W., \& Marino, R. 2006. Nitrogen as the limiting nutrient for eutrophication in coastal marine ecosystems: Evolving views over three decades. Limnology \& Oceanography. 51, 364-376. doi:10.4319/10.2006.51.1_part_2.0364.

Jeong Hae Jin. 1994. Predation by heterotrophic dinoflagellate Protoperidinium cf. divergens on copepod eggs and early naupliar stages. Marine Ecology Progress Series, 114, 203-208.

Jeong, H. J., Yoo, Y. D., Kim, S. T., \& Kang, N. S. 2004. Feeding by the heterotrophic dinoflagellate Protoperidinium bipes on the diatom Skeletonema costatum. Aquatic microbial ecology 36, 171-179.

Jeong, H. J., \& Latz, M. I. 1994. Growth and grazing rates of the heterotrophic dinoflagellates Protoperidinium spp. on red tide dinoflagellates. Marine Ecology-Progress Series 106, 173-173.

Jeong, H. J., Yoo, Y. D., Park, J. Y., Song, J. Y., Kim, S. T., Lee, S. H., Young Kim, H., \& Ho Yi, W. 2005a. Feeding by phototrophic red-tide dinoflagellates: five species newly revealed and six species previously known to be mixotrophic. Aquatic Microbial Ecology 40, 133-150. doi:10.3354/ame040133. 
709 Jeong, H. J., Park, J. Y., Nho, J. H., Park, M. O., Ha, J. H., Seong, K. A., Kim, S., Hyeon, J., \&

710

711

712

713

714

715

716

717

718

719

720

721

722

723

724

725

726

727

728

729

730

731

732

733

734

735

736

737

738

Yi, W.H. 2005b. Feeding by red-tide dinoflagellates on the cyanobacterium Synechococcus. Aquatic Microbial Ecology 41, 131-143.

Jeong, H. J., Yoo, Y. D., Seong, K. A., Kim, J. H., Park, J. Y., Kim, S., Kim, S., Hyun, J., \& Yi, W.H. 2005c. Feeding by the mixotrophic red-tide dinoflagellate Gonyaulax polygramma: mechanisms, prey species, effects of prey concentration, and grazing impact. Aquatic Microbial Ecology 38, 249-257.

Jeong, H. J., Song, J. E., Kang, N. S., Kim, S., Yoo, Y. D., \& Park, J. Y. 2007. Feeding by heterotrophic dinoflagellates on the common marine heterotrophic nanoflagellate Cafeteria sp. Marine Ecology Progress Series, 333, 151-160. doi:10.3354/meps333151

Jeong, H. J., Seong, K. A., Yoo, Y. D., Kim, T. H., Kang, N. S., Kim, S.,Park, Y., Kim, J.S., Kim, G.H., \& Song, Y.J. 2008. Feeding and Grazing Impact by Small Marine Heterotrophic Dinoflagellates on Heterotrophic Bacteria. Journal of Eukaryotic Microbiology 55, 271-288. doi:10.1111/j.1550-7408.2008.00336.x.

Jeong, H. J., Yoo, Y. D., Kim, J. S., Seong, K. A., Kang, N. S., \& Kim, T. H. 2010. Growth, feeding and ecological roles of the mixotrophic and heterotrophic dinoflagellates in marine planktonic food webs. Ocean Science Journal, 45(2), 65-91. doi:10.1007/s12601-010$0007-2$

Klein, E. \& J. Castillo. 2010. Observatorio Oceanográ- fico Digital Del Mar Venezolano. Laboratorio de Sensores Remotos, Centro de Biodiversidad Marina INTECMAR-USB (http://ood.cbm.usb.ve).

Koike Isao, Holm-Hansen Osmund, \& Biggs Douglas C. 1986. Inorganic nitrogen metabolism by Antartic phytoplankton with special reference to ammonium cycling. Marine Ecology Progress Series, 30, 105-116.

Koop, K., Booth, D., Broadbent, A., Brodie, J., Bucher, D., Capone, D., Coll, J., Denninson, W., Erdmann, N., Harrison, P., Hoegh-Guldberg, O., Hutchings, P., Jones, J.B, Larkum, A.W.D., O'neil, J., Steven, A., Tentori, E., Ward, S., Williamson, J., \& Yellowlees, D. 2001. ENCORE: The Effect of Nutrient Enrichment on Coral Reefs. Synthesis of Results and Conclusions. Marine Pollution Bulletin, 42(2), 91-120. doi:10.1016/S0025$326 \mathrm{X}(00) 00181-8$ 
739 Krayesky, D. M., Meave del Castillo, E., Zamudio, E., Norris, J. N., Fredericq, S., Tunnell jr, J.. 740 2009. Diatoms (Bacillariophyta) of the Gulf of Mexico. Felder, DL \& DK Camp. Gulf of 741 Mexico Origin, Waters, and Biota 1, 155-186.

742 La Barbera, A. 1984. Estudio taxonómico de los dinoflagelados Orden Peridinales de la 743

744 plataforma nororiental de Venezuela. Universidad de Oriente, Núcleo Cumaná, Venezuela. $245 \mathrm{pp}$.

746

La Barbera, A. 1993. Dinoflagelados de la región nororiental de Venezuela. Instituto Nacional de

747

748

749

750

751

752

753

754

755

756

757

758

759

760

761

762

763

764

765

766

767

768 Investigaciones Agrícolas. Vol 10. Cumaná, Venezuela.

Lapointe, B. E., \& Clark, M. W. 1992. Nutrient inputs from the watershed and coastal eutrophication in the Florida keys. Estuaries 15, 465-476. doi:10.2307/1352391.

Lessard, E. J., \& Swift, E. 1985. Species-specific grazing rates of heterotrophic dinoflagellates in oceanic waters, measured with a dual-label radioisotope technique. Marine Biology, 87(3), 289-296. doi:10.1007/BF00397808

Li, A., Stoecker, D. K., \& Coats, D. W. 2000. Mixotrophy in Gyrodinium galatheanum (DINOPHYCEAE): grazing responses to light intensity and inorganic nutrients*. Journal of Phycology, 36(1), 33-45. doi:10.1046/j.1529-8817.2000.98076.x

Madera, F., \& Furderer, H. 1997. Iniciación al estudio de migración del zooplancton asociado a los arrecifes coralinos circundantes a la estación biológica Dos Mosquises y su relación con la fauna ictícola. Fundación Científica Los Roques, Caracas, Venezuela.

Magurran, A.M. 2003. Measuring Biological Diversity (1st ed.). Oxford, UK: Wiley-Blackwell.

Mangubhai, S., \& Harrison, P. L. (2008). Asynchronous coral spawning patterns on equatorial reefs in Kenya. Marine Ecology Progress Series, 360, 85-96. doi:10.3354/meps07385

Marshall, H. G., \& Monitoring, E. 1986. Identification manual for phytoplankton of the United States Atlantic Coast. Environmental Monitoring and Support Laboratory, Office of Research and Development, US Environmental Protection Agency.

Mendes, J. M., \& Woodley, J. D. 2002. Effect of the 1995-1996 bleaching event on polyp tissue depth, growth, reproduction and skeletal band formation in Montastraea annularis. Marine Ecology Progress Series, 235, 93-102. doi:10.3354/meps235093

Mumby, P. J., Hastings, A., \& Edwards, H. J. 2007. Thresholds and the resilience of Caribbean coral reefs. Nature, 450(7166), 98-101. doi:10.1038/nature06252 
769 Mutshinda, C. M., Troccoli-Ghinaglia, L., Finkel, Z. V., Müller-Karger, F. E., \& Irwin, A. J.

770

771

772

773

774

775

776

777

778

779

780

781

782

783

784

785

786

787

788

789

790

791

792

793

794

795

796

797

798 2013. Environmental control of the dominant phytoplankton in the Cariaco basin: a hierarchical Bayesian approach. Marine Biology Research 9, 246-260. doi:10.1080/17451000.2012.731693.

Nelson, C. E., Alldredge, A. L., McCliment, E. A., Amaral-Zettler, L. A., \& Carlson, C. A. 2011. Depleted dissolved organic carbon and distinct bacterial communities in the water column of a rapid-flushing coral reef ecosystem. The ISME Journal, 5(8), 1374-1387. doi:10.1038/ismej.2011.12

Nelson, C. E., Goldberg, S. J., Wegley Kelly, L., Haas, A. F., Smith, J. E., Rohwer, F., \& Carlson, C. A. 2013. Coral and macroalgal exudates vary in neutral sugar composition and differentially enrich reef bacterioplankton lineages. The ISME Journal, 7(5), 962-979. doi:10.1038/ismej.2012.161

Oguz, T., Malanotte-Rizzoli, P., \& Ducklow, H. W. 2001. Simulations of phytoplankton seasonal cycle with multi-level and multi-layer physical-ecosystem models: the Black Sea example. Ecological Modelling 144, 295-314. doi:10.1016/S0304-3800(01)00378-7.

Patten, N. L., Harrison, P. L., \& Mitchell, J. G. 2008. Prevalence of virus-like particles within a staghorn scleractinian coral (Acropora muricata) from the Great Barrier Reef. Coral Reefs, 27(3), 569-580. doi:10.1007/s00338-008-0356-9

Peragallo, H., \& Peragallo, M. 1897-1908. Diatomées marines de France et dies districts maritimes voisins. Grez del Loig.

Piehler, M. F., Twomey, L. J., Hall, N. S., \& Paerl, H. W. 2004. Impacts of inorganic nutrient enrichment on phytoplankton community structure and function in Pamlico Sound, NC, USA. Estuarine, Coastal and Shelf Science 61, 197-209.

Pomeroy, L., leB. Williams, P., Azam, F., \& Hobbie, J. 2007. The Microbial Loop. Oceanography, 20(2), 28-33. doi:10.5670/oceanog.2007.45

Reynolds, C. S. 2006. The ecology of phytoplankton. Cambridge University Press.

Rodríguez-Centeno, M. E., Díaz-Ramos, J.R., Charzeddine, L., Subero-Pino, S., \& TroccoliGhinaglia, L. 2010. Biomasa y Abundancia del Fitoplancton en la Isla la Tortuga, Depdendencia Federal, Venezuela. Boletin Instituto Oceanografico de Venezuela, 79(1), 76-86. 
799 Rodríguez-Ramírez, A., Bastidas, C., Rodríguez, S., Leao, Z., Kikuchi, R., Oliveira M., Gil, D., 800 Garzón-Ferreira, J., Reyes-Nivia, R., Navas-Camacho, R., Santodomingo, N., Díaz-Pulido, 801 G., Venera-Ponton, D., Flores-Leiva, L., Rangel-Campo, A., Orozco, C., Marquez, J., 802 803 804 805 806 807 808 809

810

811

813

814 815 López-Victoria, M., Sánchez, J., \& Hurtado, M.C. 2008. The effects of Coral Bleaching in Southern Tropical America: Brazil, Colombia and Venezuela. In Souter, C.W.D. (Ed.), Status of Caribbean Coral Reefs After Bleaching and Hurricanes in 2005 (1st ed., pp. 105114). Townsville: GCRMN.

Sánchez, J. A., Alvarado, E. M., Gil, M. F., Charry, H., Arenas, O. L., Chasqui, L. H., \& García, R. P. 1999. Synchronous mass spawning of Montastraea annularis (Ellis \& Solander) and Montastraea faveolata (Ellis \& Solander) (Faviidae: Scleractinia) at Rosario Islands, Caribbean coast of Colombia. Bulletin of Marine Science, 65(3), 873-879.

Sánchez-Suárez, I. G. 1992. Coccolithophorids (Haptophyta) from South-Eastern Caribbean Sea: II. Orders Coccolithales and Eiffelithales. Acta Científica Venezolana 43, 34-44.

Sánchez-Suárez, I. G. 1992. Coccolithophorids (Haptophyta) from South-Eastern Caribbean Sea: II. Order Syracospherales. Acta Científica Venezolana 43, 109-124.

Saunders, R. P., \& Glenn, D. H. 1969. "Diatoms," in Memoirs of the Hourglass Cruises (Florida, USA), 1-119.

816 Santos, I. R., Erler, D., Tait, D., \& Eyre, B. D. 2010. Breathing of a coral cay: Tracing tidally 817 818 driven seawater recirculation in permeable coral reef sediments. Journal of Geophysical

819 Research. 115, C12010. doi:10.1029/2010JC006510.

Seong, H. J., Yoo, Y. D., Kang, N. S., Rho, J. R., Seong, K. A., Park, J. W., Nam, G.S., \& Yi, W. 820 821 2010. Ecology of Gymnodinium aureolum. I. Feeding in western Korean waters. Aquatic Microbial Ecology 59, 239-255.

822 Sournia, A. 1986. Atlas phytoplancton marin: Volume 2, Diatomophycées.

823 Sournia, A. 1973. Catalogue des espéces ettaxons infraspécifiques de dinoflagellés marins 824 actuels publiés despueis la revision de J. Schiller I. Dinoflagellés libres. Beih. Nova Hedw $82548,1-92$.

826 Spiniello, P. 1996. Las Diatomeas Marino-Costeras de Venezuela. Caribbean Journal of Science, 827 32(4), 331-347.

828 Sridhar, R., Thangaradjou, T., \& Kannan, L. 2010. Spatial and temporal variations in 829 phytoplankton in coral reef and seagrass ecosystems of the Palk Bay, southeast coast of 
830

831

832

833

834

835

836

837

838

839

840

841

842

843

844

845

846

847

848

849

850

851

852

853

854

855

856

857

858

India. http://www.jeb.co.in/journal_issues/201009_sep10_supp/paper_06.pdf. Available at: http://imsear.hellis.org/handle/123456789/146493

Stolte, W., McCollin, T., Noordeloos, A. A. M., \& Riegman, R. 1994. Effect of nitrogen source on the size distribution within marine phytoplankton populations. Journal of Experimental Marine Biology and Ecology, 184(1), 83-97. doi:10.1016/0022-0981(94)90167-8

Strom, S. L. 2008. Microbial Ecology of Ocean Biogeochemistry: A Community Perspective. Science 320, 1043-1045. doi:10.1126/science.1153527.

Szmant, A. 2002. Nutrient Enrichment on coral reefs: is it major cause of coral reef decline? Estuaries, 25(4b), 83-97.

Szmant, A. M., Weil, E., Miller, M. W., \& Colón, D. E. 1997. Hybridization within the species complex of the scleractinan coral Montastraea annularis. Marine Biology, 129(4), 561-572. doi: $10.1007 / \mathrm{s} 002270050197$

Szmant, A. M. 1986. Reproductive ecology of Caribbean coral reefs. Coral Reef, 5,43-54.

Tomas, C. R. 1997. Identifying marine phytoplankton. Academic press.

Van Duyl, F., Gast, G., Steinhoff, W., Kloff, S., Veldhuis, M., \& Bak, R. 2002. Factors influencing the short-term variation in phytoplankton composition and biomass in coral reef waters. Coral Reefs 21, 293-306. doi:10.1007/s00338-002-0248-3.

Van Veghel, M.L, \& Kahmann, M.E. 1994. Reproductive characteristics of the polymorphic Caribbean reef building coral Montastraea annularis. II. Fecundity and colony structure. Marine Ecology Progress Series, 109, 209-219.

Vuorio, K., Lagus, A., Lehtimäki, J. M., Suomela, J., \& Helminen, H. 2005. Phytoplankton community responses to nutrient and iron enrichment under different nitrogen to phosphorus ratios in the northern Baltic Sea. Journal of Experimental Marine Biology and Ecology 322, 39-52. doi:10.1016/j.jembe.2005.02.006.

Westneat, M. W., \& Resing, J. M. 1988. Predation on coral spawn by planktivorous fish. Coral Reefs, 7(2), 89-92. doi:10.1007/BF00301646

Wild, C., Huettel, M., Klueter, A., Kremb, S. G., Rasheed, M. Y. M., \& Jørgensen, B. B. $2004 a$. Coral mucus functions as an energy carrier and particle trap in the reef ecosystem. Nature, 428(6978), 66-70. doi:10.1038/nature02344 
859 Wild, C., Tollrian, R., \& Huettel, M. 2004b. Rapid recycling of coral mass-spawning products in

860

861

862

863

864

865

866

867

868

869

870

871

872

873

874

875

876

877

878

879

880

881

882

883 permeable reef sediments. Marine Ecology Progress Series, 271, 159-166. doi:10.3354/meps271159

Wild, C., Jantzen, C., Struck, U., Hoegh-Gludberg, O., \& Huettel, M. 2008. Biogeochemical responses following coral mass spawning on the Great Barrier Reef: pelagic-benthic coupling. Coral Reefs, 27(1), 123-132. doi:10.1007/s00338-007-0298-7

Willén, E. 1991. Planktonic diatoms-an ecological review. Algological Studies 62, 61-106.

Wolanski, E., Richmond, R. H., \& McCook, L. 2004. A model of the effects of land-based, human activities on the health of coral reefs in the Great Barrier Reef and in Fouha Bay, Guam, Micronesia. Journal of Marine Systems, 46(1-4), 133-144. doi:10.1016/j.jmarsys.2003.11.018

Wright, S. W. \& Jeffrey, S. W. 2006. Pigment Markers for Phytoplank- ton Production, in: Marine Organic Matter: Biomarkers, Isotopes and DNA, edited by: Volkman, J., The Handbook of Environ- mental Chemistry, Springer Berlin Heidelberg.

Wu, Y., Sun, S., \& Zhang, Y. 2005. Long-term change of environment and it's influence on phytoplankton community structure in Jiaozhou Bay. Oceanologia et Limnologia Sinica $36,498$.

Zubillaga, A. L., Bastidas, C., \& Cróquer, A. 2005. High densities of the Elkhorn coral Acropora palmata in Cayo de Agua, Archipelago Los Roques National Park, Venezuela. Coral Reefs, 24(1), 86-86. doi:10.1007/s00338-004-0458-y

Zubillaga, A. L. 2010. El Coral Acropora palmata: Comportamiento, distribución larval y conectividad genética en Caribe. Available at: http://159.90.80.10/F/RBM9JE9MJI591UTFDYQXIQPIB4YDEH66RVKKGG3YR3LS4 NDR4N-29121 func $=$ full-set-set\&set_number $=905390 \&$ set_entry $=000001 \&$ format $=999$.

\section{Figures}




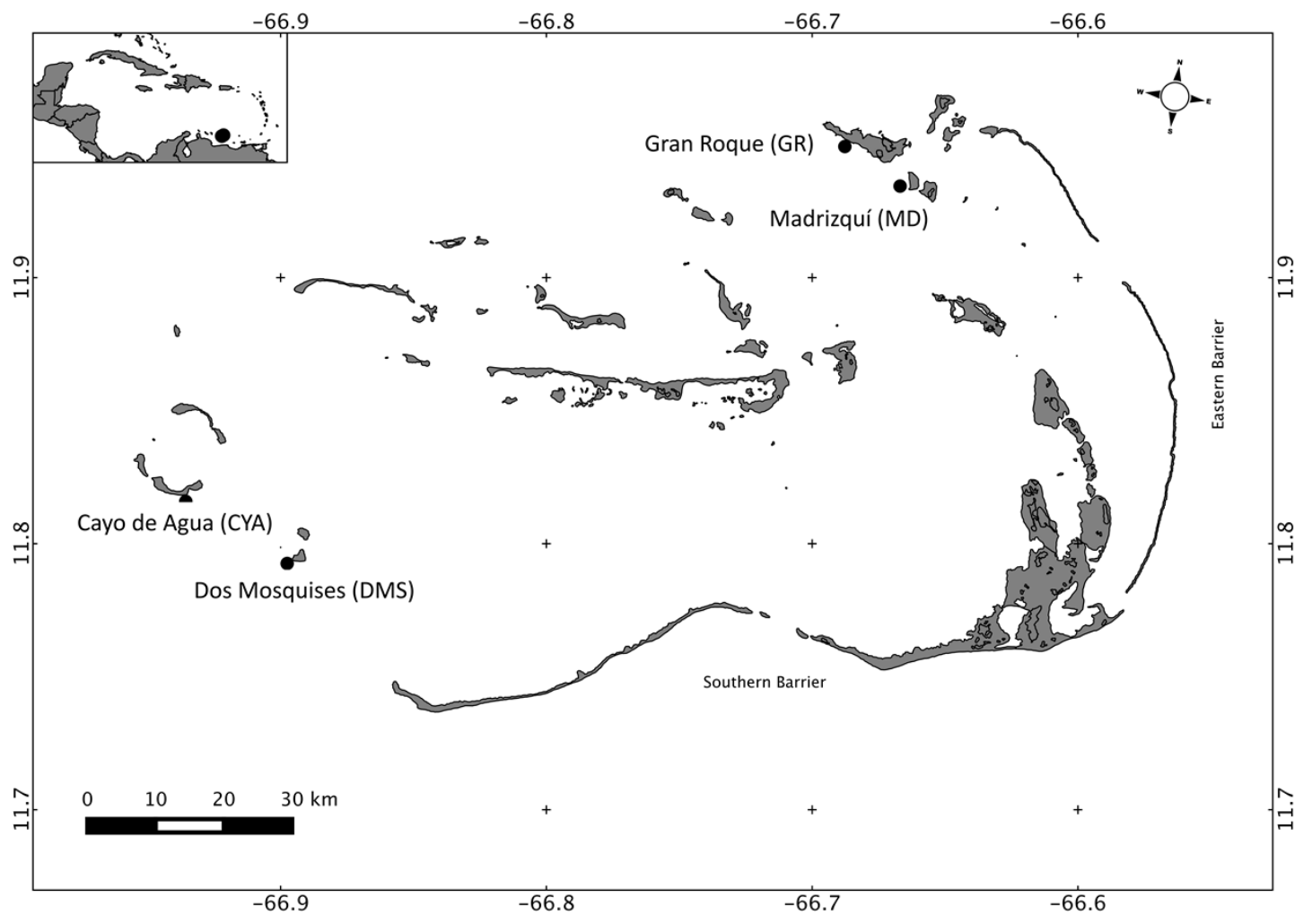

885 Figure 1. Map of Los Roques National Park, Venezuela, Southern Caribbean, showing the four reefs sampled at the Northeast (NE) and Southwest (SW) sectors. 

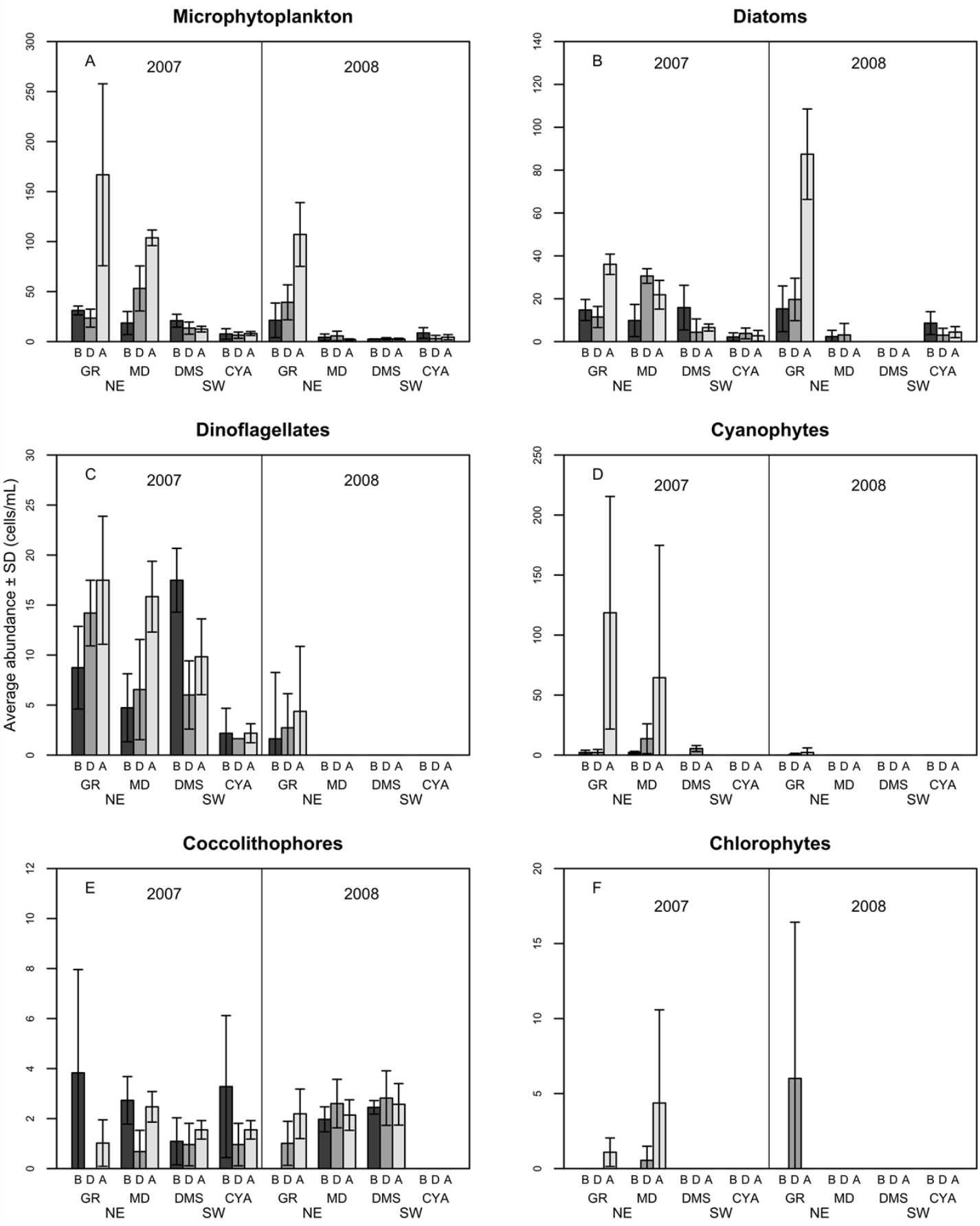

Figure 2. Average density of microphytoplankton (cells per $\mathrm{mL}$ ) of Microphytoplankton (A),

890 in four reefs (GR, MD, DMS, CYA) located at the Northeast (NE) and Southwest (SW) localities

891 of Los Roques. B, D, A refers to Before, During and After the coral spawning events of 2007 and 892 2008. Density values are displayed with different scales for each of the taxonomic groups. 
Diatoms

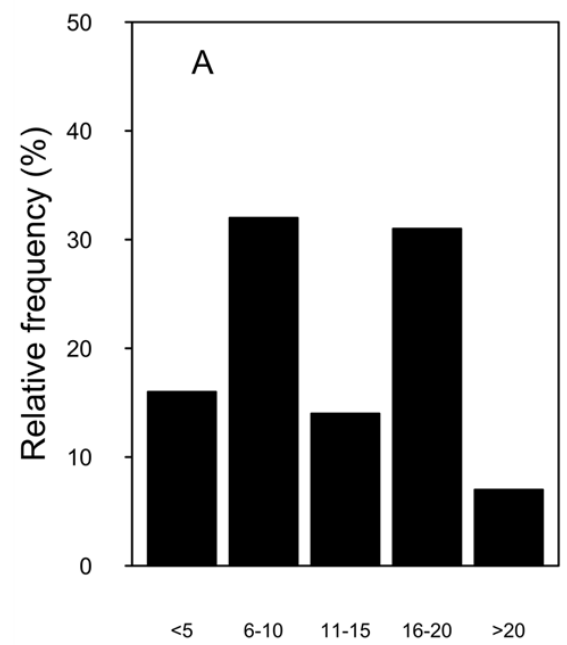

893

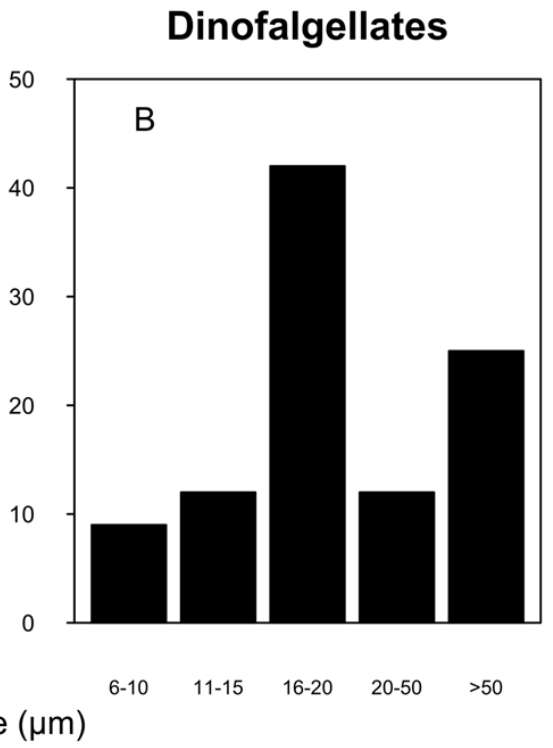

894 Figure 3. Relative frequency of the Diatoms (A) and Dinoflagellate (B) groups size classes 895 sampled in four reefs (GR, MD, DMS, CYA) located at the Northeast (NE) and Southwest (SW) 896 localities of Los Roques during 9 consecutive days in August and September 2007 and 2008.
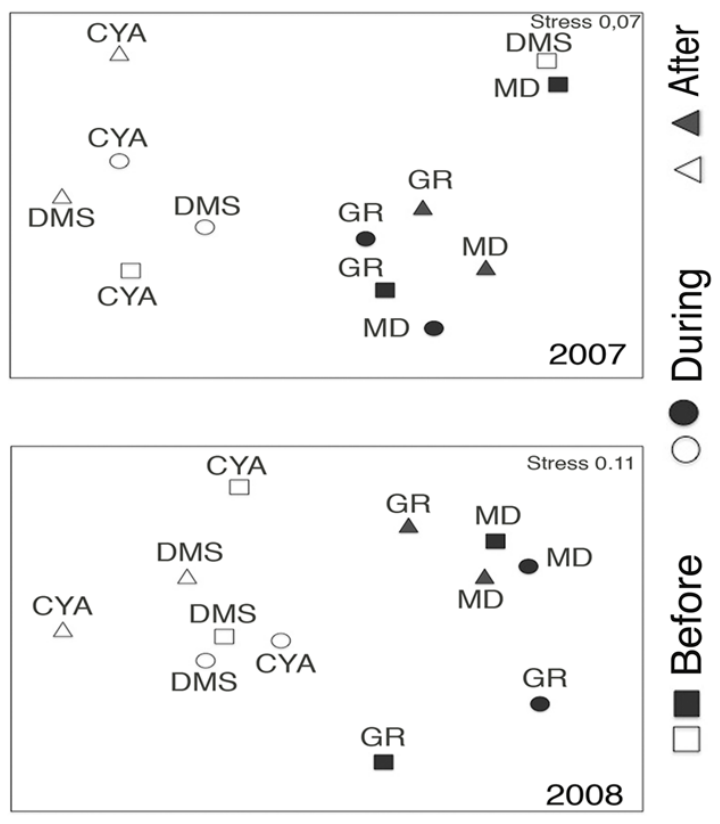

898 Figure 4. Nonmetric Multidimentional Ordination (nMDS) based on centroids for the 899 microphytoplankton assemblages in four reefs (GR, MD, DMS, CYA), located in the Northeast 900 (empty symbols) and Southwest (filled symbols) of Los Roques. 
901

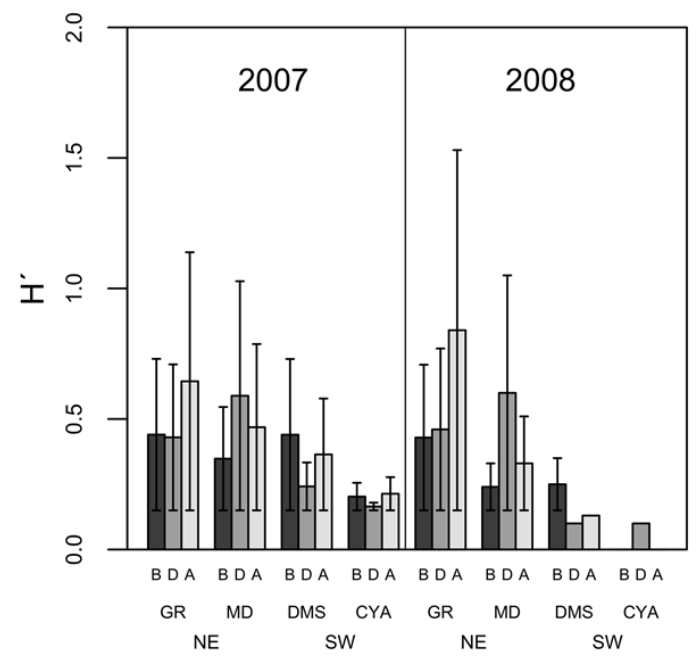

902

903 Figure 5. Average Shannon Diversity index values $\left(H^{\prime} \pm \mathrm{SD}\right)$ of microphytoplankton in four 904 reefs (GR, MD, DMS, CYA) located at the Northeast (NE) and Southwest (SW) localities of Los 905 Roques. B, D, A refer to Before, During and After the coral spawning events of 2007 and 2008. 


\section{Heterotrophic}

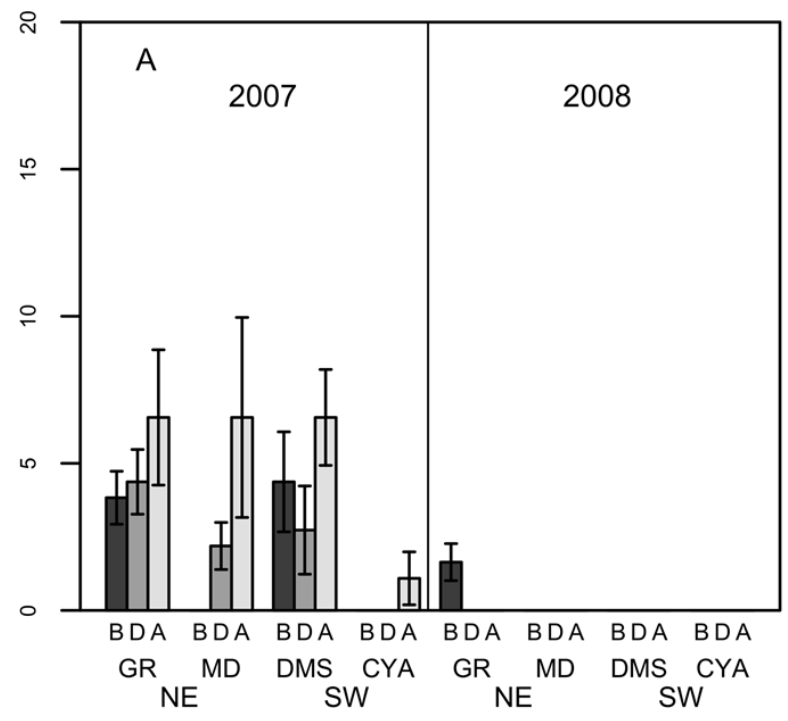

Mixotrophic

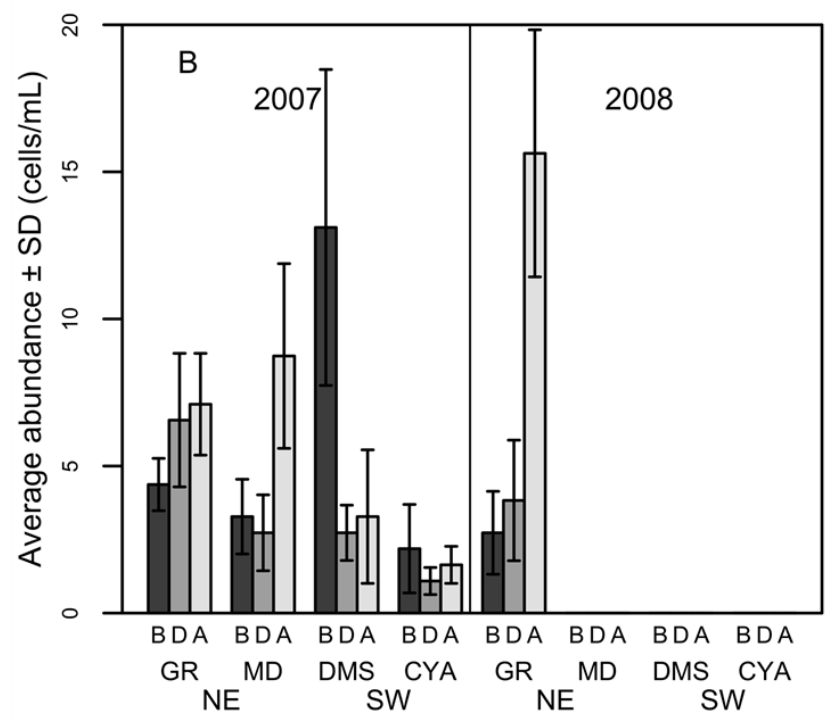

Autotrophic

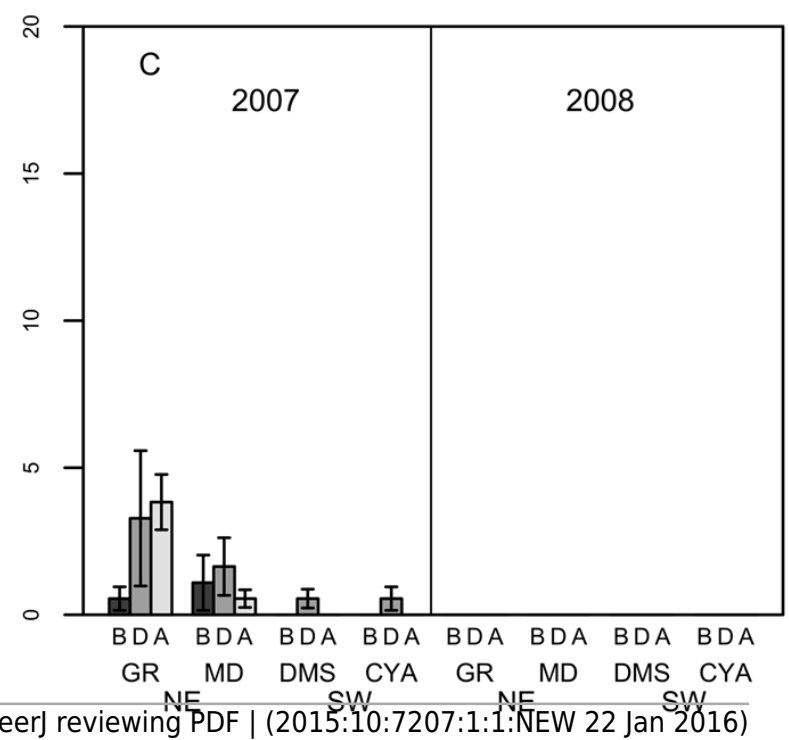


907 Figure 6. Density of Heterotrophic (A), Mixotrophic (B) and Autotrophic (C) dinoflagellates 908 (cells per millilitre, Mean \pm SD) in four reefs (GR, MD, DMS, CYA) located at the Northeast 909 (NE) and Southwest (SW) localities of Los Roques. B, D, A refers to Before, During and After 910 the coral spawning event of 2007.
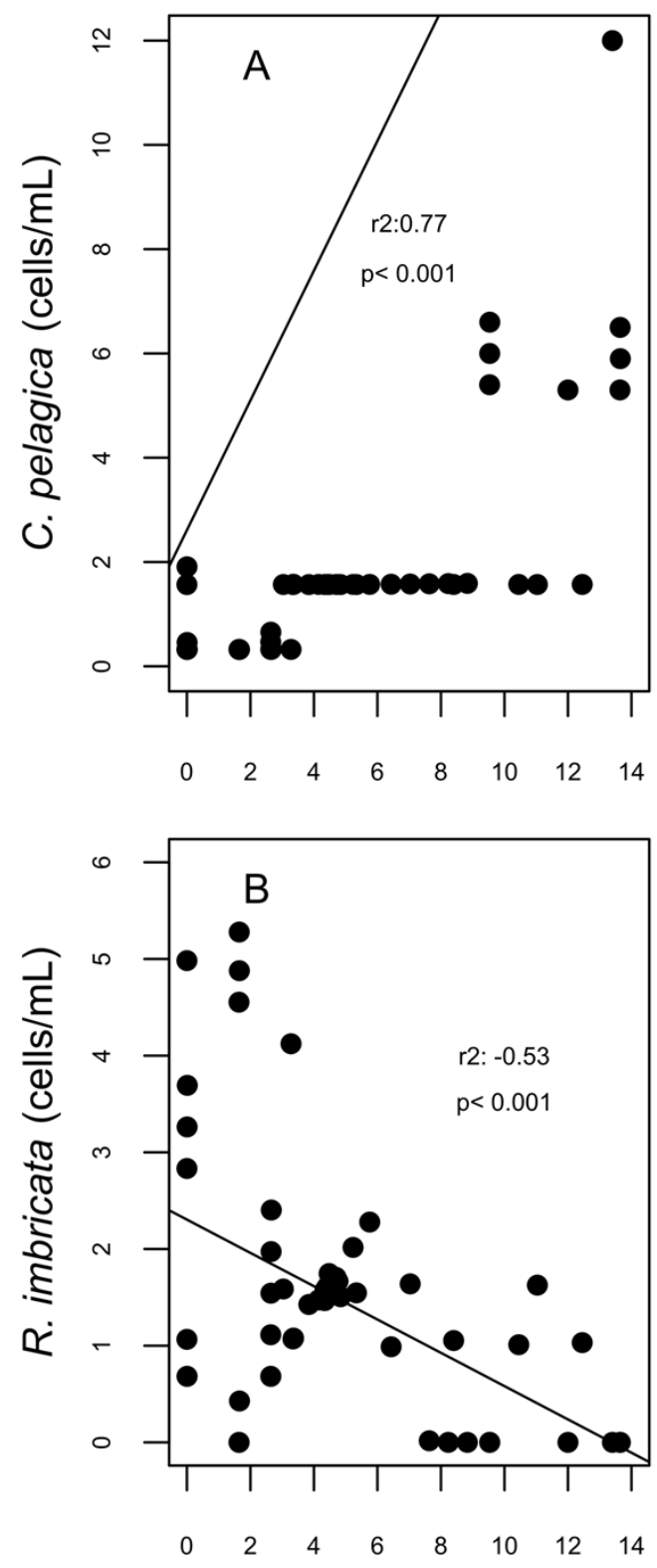

Protoperidinium species (cells $/ \mathrm{mL}$ )

912 Figure 7. Correlation plots on abundances of Cerataulina pelagica (A) and Rhizosolenia 913 imbricata (B) and the abundance of Protoperidinium species; corresponding to the spawning 
914 event of 2007 in two reefs (DMS, CYA) located at the Southwest (SW) sector of Los Roques. 915 Only statistically significant $(\mathrm{p}<0.05)$ correlations, with Spearman $\mathrm{r}^{2}$ values are shown. 916 Abundance values in cell per millilitres are displayed with different scales for each of the 917 correlation plots.
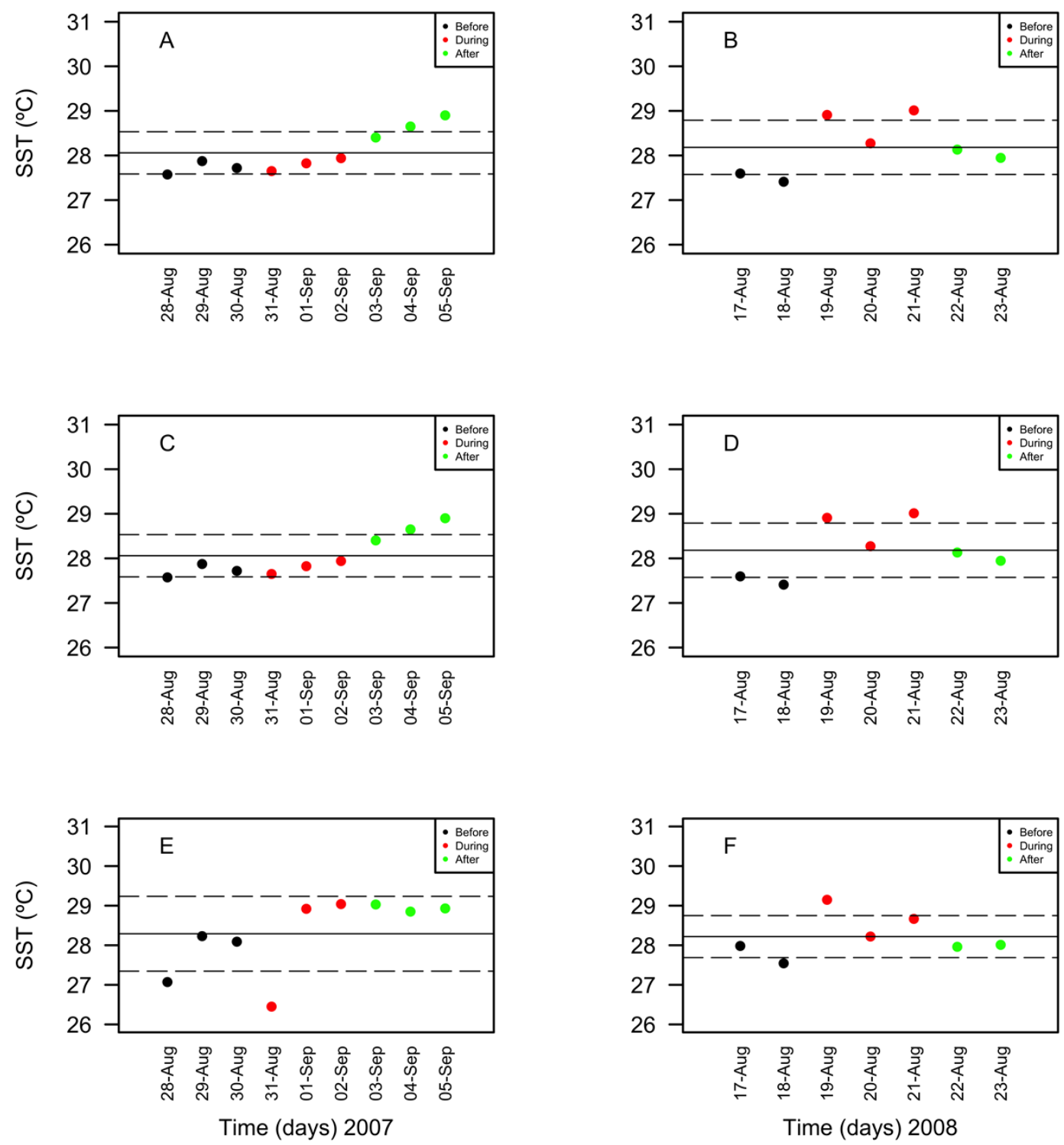

919 Figure 8. Surface seawater temperature (SST in $\left.{ }^{\circ} \mathrm{C}\right)$ values obtained through remote sensing 920 (MODIS SCAR, $1 \mathrm{~km} \times 1 \mathrm{Km}$ resolution) for the nine-days sampling period corresponding to 921 Before (black), During (red) and After (green) expected coral spawning times for the study site, 
922 at the Northeast (A-B) and Southwest (SW) Cayo de Agua (C-D) and Dos Mosquises (E-F) reefs 923 of Los Roques in 2007 and 2008.
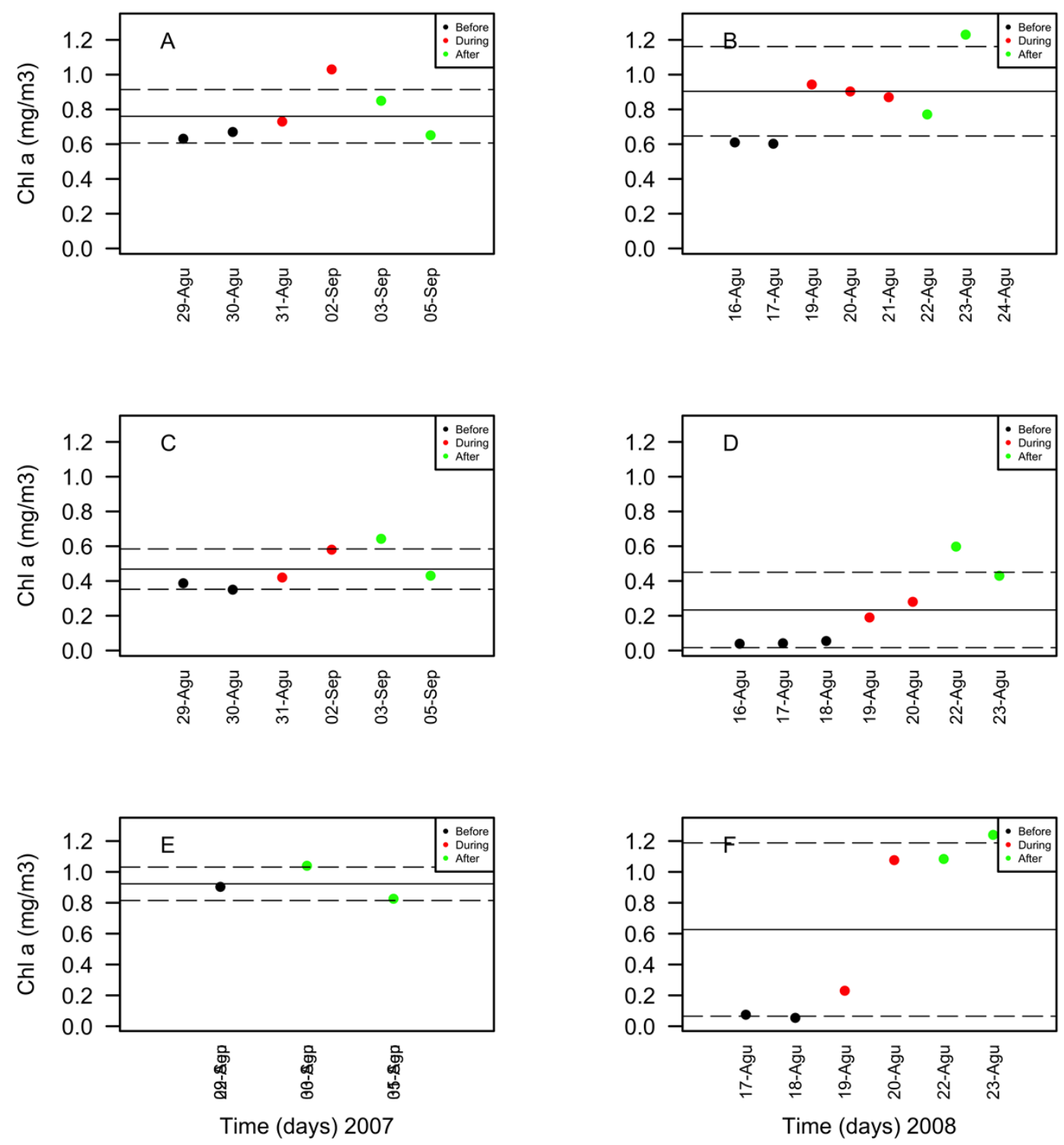

925 Figure 9. Chlorophyll $a\left(\mathrm{Chl} a\right.$ in $\left.\mathrm{mg} / \mathrm{m}^{3}\right)$ values obtained through remote sensing (MODIS $926 \mathrm{SCAR}, 1 \mathrm{~km} \times 1 \mathrm{Km}$ resolution) for the nine-days sampling period corresponding to Before 927 (black), During (red) and After (green) expected coral spawning times for the study site, at the 928 Northeast (A-B) and Southwest (SW) Cayo de Agua (C-D) and Dos Mosquises (E-F) reefs of 929 Los Roques in 2007 and 2008. 